\title{
LEVEL II SCOUR ANALYSIS FOR BRIDGE 9 (BARRUS03020009) on U.S. ROUTE 302, crossing JAIL BRANCH, BARRE, VERMONT
}

U.S. Geological Survey Open-File Report 97-109

Prepared in cooperation with

VERMONT AGENCY OF TRANSPORTATION and

FEDERAL HIGHWAY ADMINISTRATION 


\section{LEVEL II SCOUR ANALYSIS FOR BRIDGE 9 (BARRUS03020009) on U.S. ROUTE 302, crossing JAIL BRANCH, BARRE, VERMONT}

By SCOTT A. OLSON and MICHAEL A. IVANOFF

U.S. Geological Survey Open-File Report 97-109

Prepared in cooperation with

VERMONT AGENCY OF TRANSPORTATION

and

FEDERAL HIGHWAY ADMINISTRATION 


\title{
U.S. DEPARTMENT OF THE INTERIOR BRUCE BABBITT, Secretary
}

\author{
U.S. GEOLOGICAL SURVEY \\ Gordon P. Eaton, Director
}

For additional information write to:

District Chief

U.S. Geological Survey 361 Commerce Way

Pembroke, NH 03275-3718
Copies of this report may be purchased from:

U.S. Geological Survey

Branch of Information Services

Open-File Reports Unit

Box 25286

Denver, CO 80225-0286 


\section{CONTENTS}

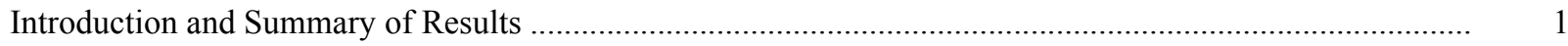

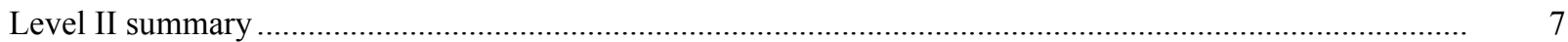

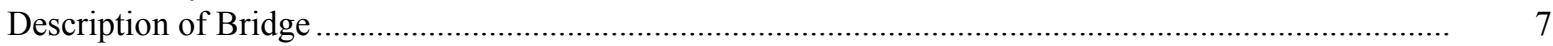

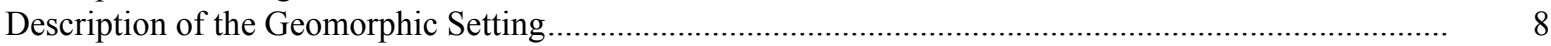

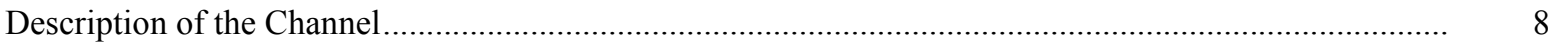

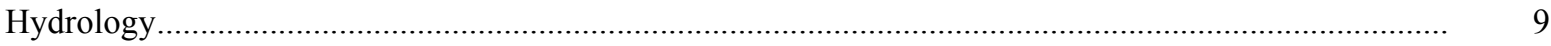

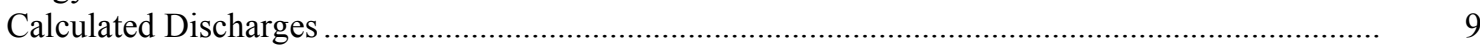

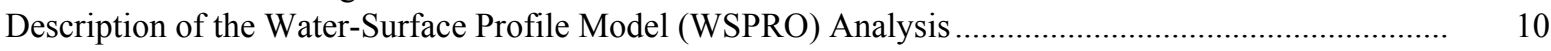

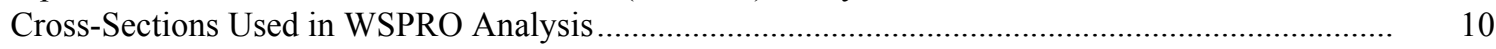

Data and Assumptions Used in WSPRO Model ..................................................................... 11

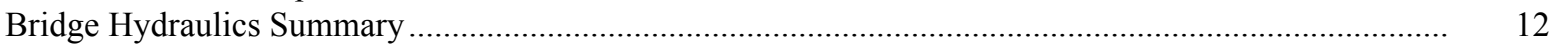

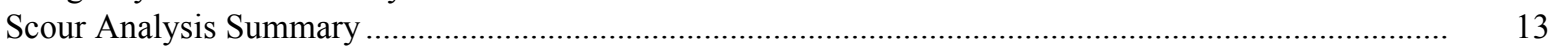

Special Conditions or Assumptions Made in Scour Analysis ...................................................... 13

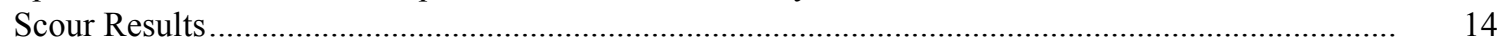

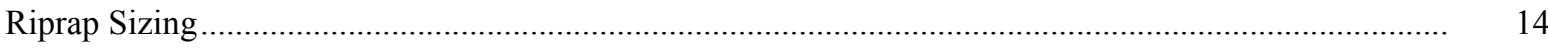

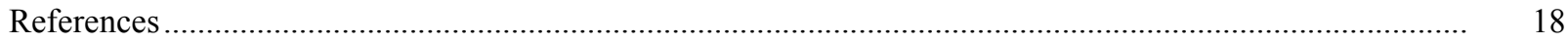

Appendixes:

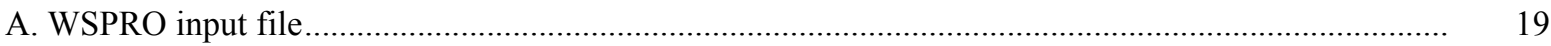

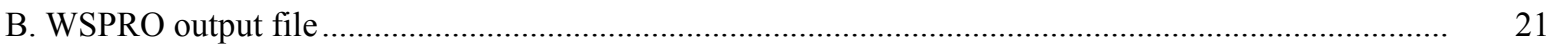

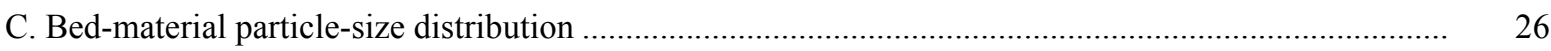

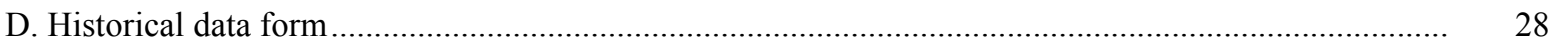

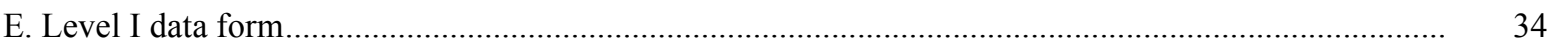

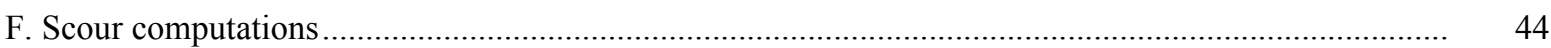

\section{FIGURES}

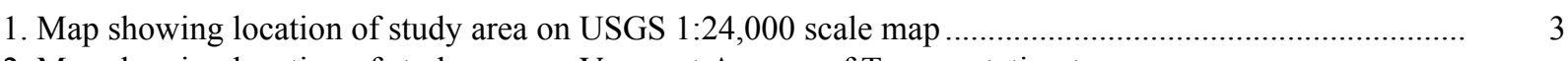

2. Map showing location of study area on Vermont Agency of Transportation town
highway map

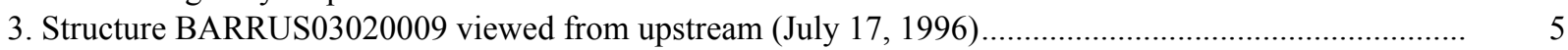

4. Downstream channel viewed from structure BARRUS03020009 (July 17, 1996).............................. 5

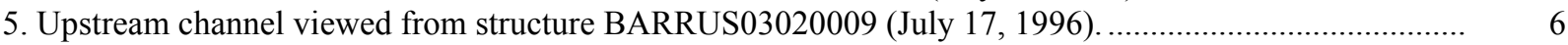

6. Structure BARRUS03020009 viewed from downstream (July 17, 1996)......................................... 6

7. Water-surface profiles for the 100- and 500-year discharges at structure

BARRUS03020009 on U.S. Route 302, crossing Jail Branch,

Barre, Vermont.

8. Scour elevations for the 100- and 500-year discharges at structure

BARRUS03020009 on U.S. Route 302, crossing Jail Branch,

Barre, Vermont.

\section{TABLES}

1. Remaining footing/pile depth at abutments for the 100-year discharge at structure

BARRUS03020009 on U.S. Route 302, crossing Jail Branch,

Barre, Vermont.

2. Remaining footing/pile depth at abutments for the 500-year discharge at structure

BARRUS03020009 on U.S. Route 302, crossing Jail Branch,

Barre, Vermont.

5
(5 


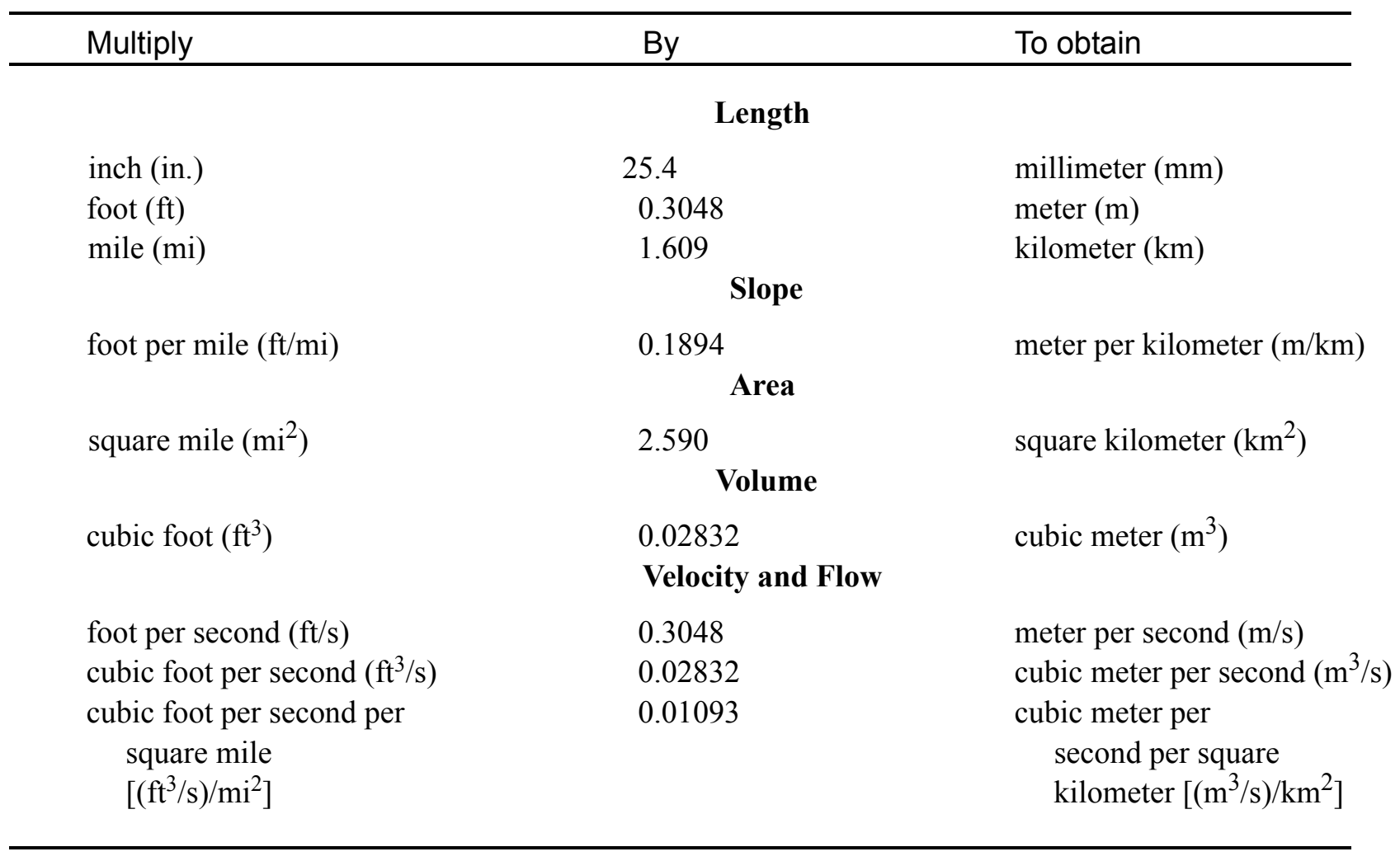

\section{OTHER ABBREVIATIONS}

$\begin{array}{lrlr}\mathrm{BF} & \text { bank full } & \text { LWW } & \text { left wingwall } \\ \mathrm{cfs} & \text { cubic feet per second } & \text { MC } & \text { main channel } \\ \mathrm{D}_{50} & \text { median diameter of bed material } & \text { RAB } & \text { right abutment } \\ \mathrm{DS} & \text { downstream } & \text { RABUT } & \text { face of right abutment } \\ \mathrm{elev} & \text { elevation } & \text { RB } & \text { right bank } \\ \mathrm{f} / \mathrm{p} & \text { flood plain } & \text { ROB } & \text { right overbank } \\ \mathrm{ft}^{2} & \text { square feet } & \text { RWW } & \text { right wingwall } \\ \mathrm{ft} / \mathrm{ft} & \text { feet per foot } & \text { TH } & \text { town highway } \\ \mathrm{JCT} & \text { junction } & \text { UB } & \text { under bridge } \\ \mathrm{LAB} & \text { left abutment } & \text { US } & \text { upstream } \\ \mathrm{LABUT} & \text { face of left abutment } & \text { USGS } & \text { United States Geological Survey } \\ \mathrm{LB} & \text { left bank } & \text { VTAOT Vermont Agency of Transportation } \\ \mathrm{LOB} & \text { left overbank } & \text { WSPRO } & \text { water-surface profile model }\end{array}$

In this report, the words "right" and "left" refer to directions that would be reported by an observer facing downstream. Sea level: In this report, "sea level" refers to the National Geodetic Vertical Datum of 1929-- a geodetic datum derived from a general adjustment of the first-order level nets of the United States and Canada, formerly called Sea Level Datum of 1929.

In the appendices, the above abbreviations may be combined. For example, USLB would represent upstream left bank. 


\title{
LEVEL II SCOUR ANALYSIS FOR BRIDGE 9 (BARRUS03020009) ON U.S. ROUTE 302, CROSSING JAIL BRANCH, BARRE, VERMONT
}

\author{
By Scott A. Olson and Michael A. Ivanoff
}

\section{INTRODUCTION AND SUMMARY OF RESULTS}

This report provides the results of a detailed Level II analysis of scour potential at structure BARRUS03020009 on U.S. Route 302 crossing Jail Branch, Barre, Vermont (figures 1-8). A Level II study is a basic engineering analysis of the site, including a quantitative analysis of stream stability and scour (U.S. Department of Transportation, 1993). Results of a Level I scour investigation also are included in Appendix E of this report. A Level I investigation provides a qualitative geomorphic characterization of the study site. Information on the bridge, gleaned from Vermont Agency of Transportation (VTAOT) files, was compiled prior to conducting Level I and Level II analyses and is found in Appendix D.

The site is in the New England Upland section of the New England physiographic province in central Vermont. The $42.8-\mathrm{mi}^{2}$ drainage area is in a predominantly rural and forested basin. A flood control reservoir with a usable capacity of 525 million cubic feet is located just upstream of the bridge. In the vicinity of the study site, the surface cover left of the channel consists of trees and brush. Right of the channel, the immediate bank is covered by trees and brush while the overbank is grass covered with several buildings.

In the study area, Jail Branch has an incised, sinuous channel with a slope of approximately $0.008 \mathrm{ft} / \mathrm{ft}$, an average channel top width of $86 \mathrm{ft}$ and an average channel depth of $5 \mathrm{ft}$. The channel bed material ranged from gravel to boulder with a median grain size $\left(D_{50}\right)$ of 73.5 $\mathrm{mm}(0.241 \mathrm{ft})$. The geomorphic assessment at the time of the Level I and Level II site visit on July 17, 1996, indicated that the reach was laterally unstable due to its sinuosity, cut banks, point bars, and extensive bank protection.

The U.S. Route 302 crossing of Jail Branch is a 74-ft-long, two-lane bridge consisting of one 72-foot steel-beam span (Vermont Agency of Transportation, written communication, October 13, 1995). The bridge is supported by vertical, concrete abutments with wingwalls. The channel is skewed approximately 30 degrees to the opening while there is no openingskew-to-roadway. 
There is evidence of channel scour along the right bank from 190 feet upstream of the bridge and extending through the bridge along the right abutment. Under the bridge, the scour depth is approximately 0.5 feet below the mean thalweg depth. Scour protection measures at the site include type- 3 stone fill (less than 48 inches diameter) along the right bank extending from the bridge to 192 feet upstream. Type- 2 stone fill (less than 36 inches diameter) is along the right abutment and the right downstream bank to 205 feet downtream of the bridge. Additional details describing conditions at the site are included in the Level II Summary and Appendices D and E.

Scour depths and rock rip-rap sizes were computed using the general guidelines described in Hydraulic Engineering Circular 18 (Richardson and others, 1995). Total scour at a highway crossing is comprised of three components: 1) long-term streambed degradation; 2) contraction scour (due to accelerated flow caused by a reduction in flow area at a bridge) and; 3) local scour (caused by accelerated flow around piers and abutments). Total scour is the sum of the three components. Equations are available to compute depths for contraction and local scour and a summary of the results of these computations follows.

Contraction scour for all modelled flows ranged from 0.2 to $0.5 \mathrm{ft}$. The worst-case contraction scour occurred at the 500-year discharge. Abutment scour ranged from 4.3 to $7.5 \mathrm{ft}$. The worst-case abutment scour occurred at the 500-year discharge. Computed scour for the 100-year event does not go below the abutment footings. Additional information on scour depths and depths to armoring are included in the section titled "Scour Results". Scoured-streambed elevations, based on the calculated scour depths, are presented in tables 1 and 2. A cross-section of the scour computed at the bridge is presented in figure 8. Scour depths were calculated assuming an infinite depth of erosive material and a homogeneous particle-size distribution.

It is generally accepted that the Froehlich equation (abutment scour) gives "excessively conservative estimates of scour depths" (Richardson and others, 1995, p. 47). Usually, computed scour depths are evaluated in combination with other information including (but not limited to) historical performance during flood events, the geomorphic stability assessment, existing scour protection measures, and the results of the hydraulic analyses. Therefore, scour depths adopted by VTAOT may differ from the computed values documented herein. 


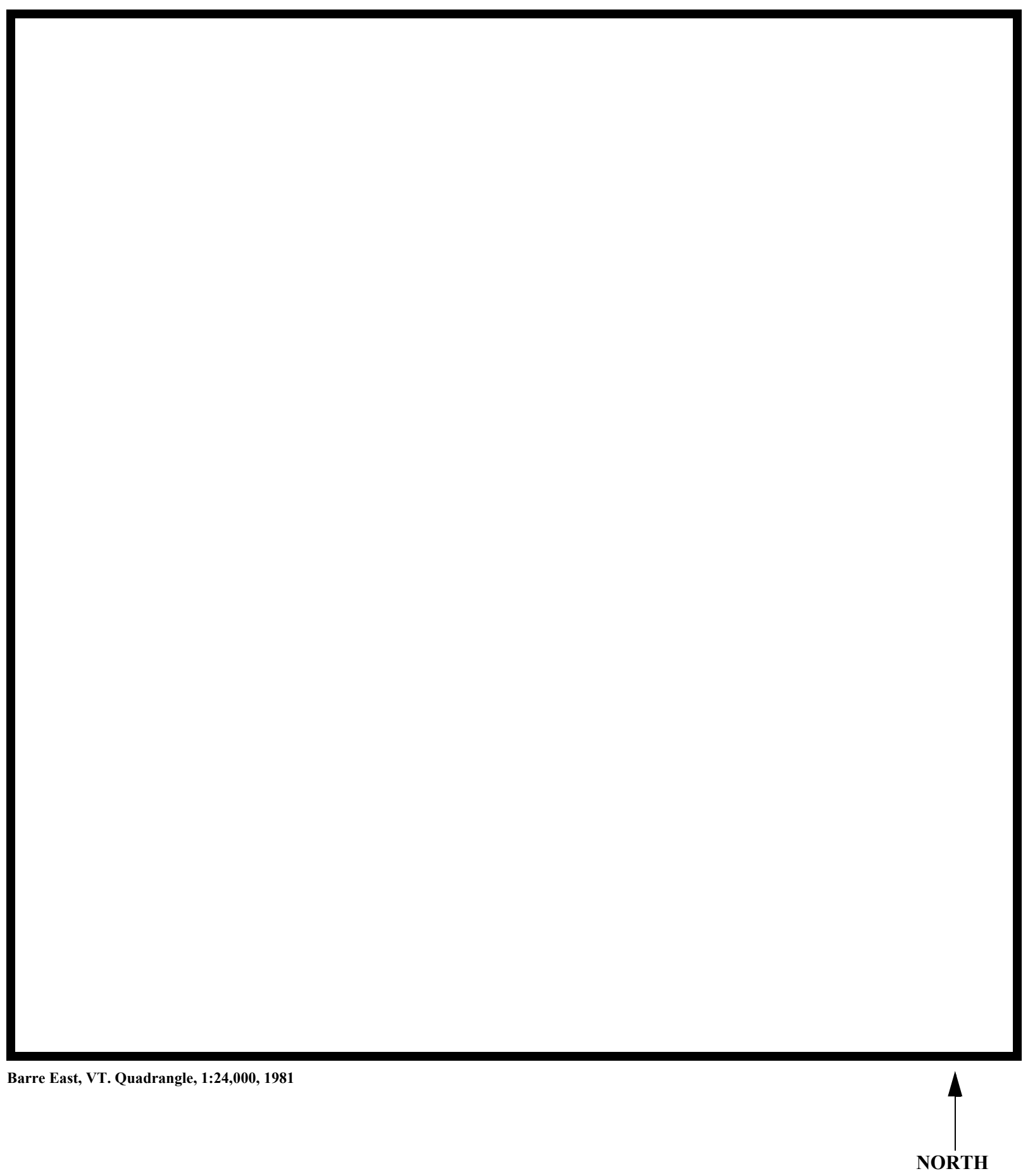

Figure 1. Location of study area on USGS 1:24,000 scale map. 
Figure 2. Location of study area on Vermont Agency of Transportation U.S. route map. 

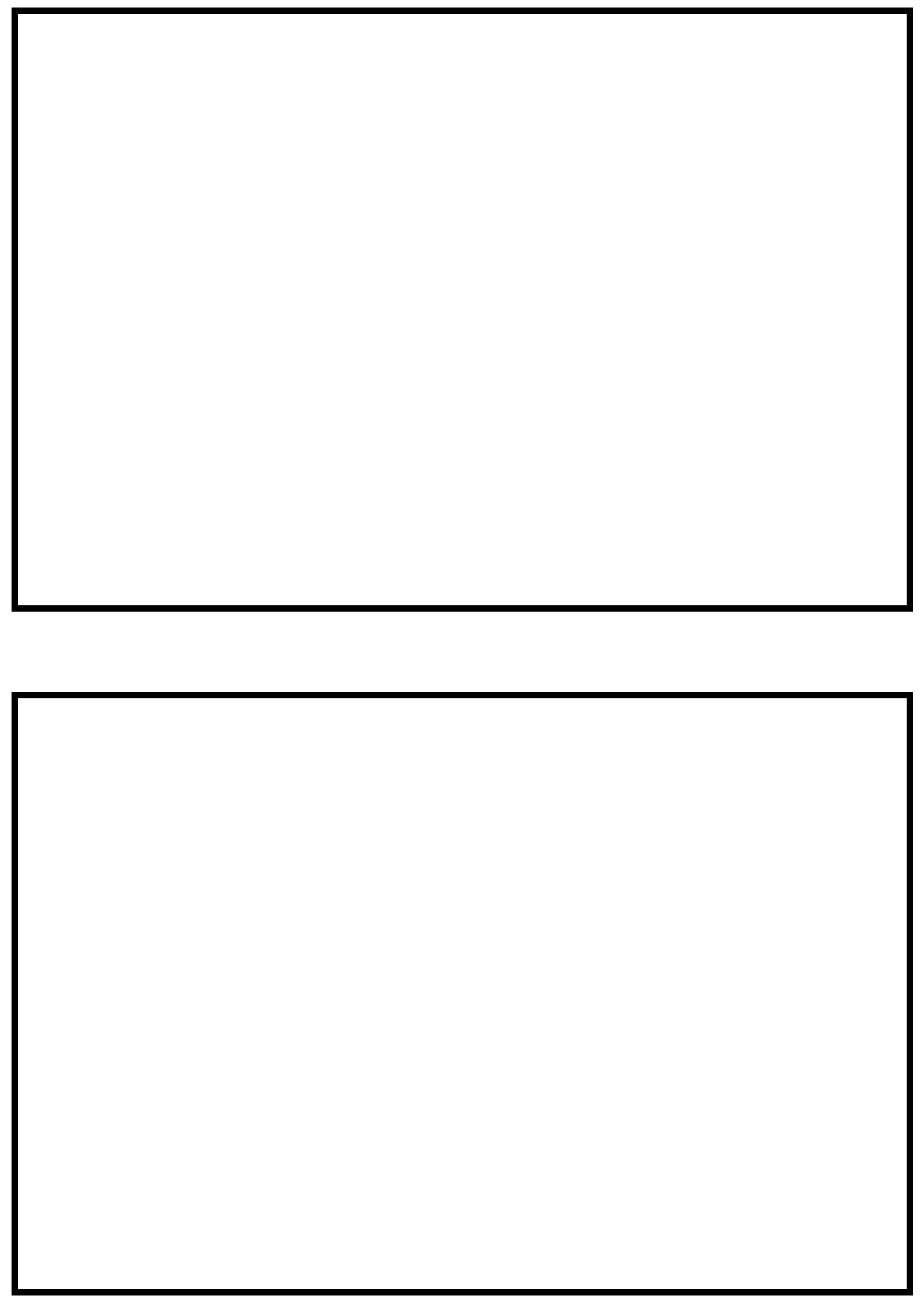

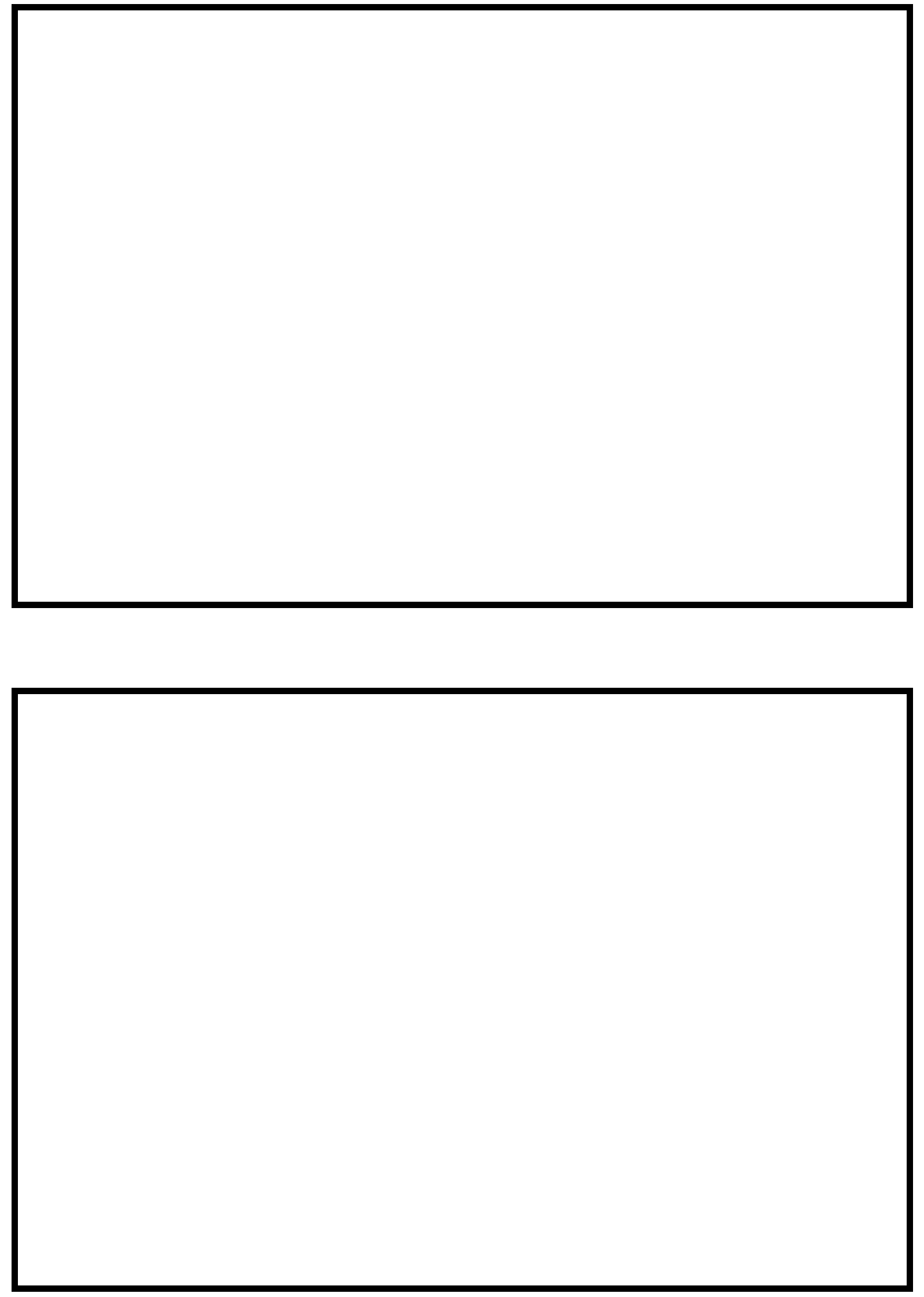


\section{LEVEL II SUMMARY}

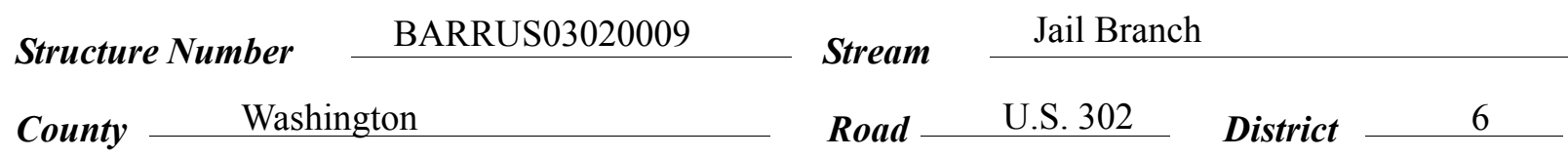

\section{Description of Bridge}

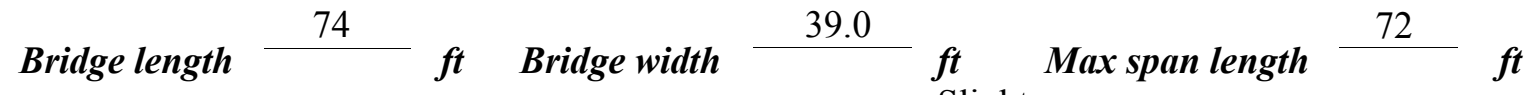
Alignment of bridge to road (on curve or straight)

Abutment type Vertical, concrete

Stone fill on abutment? On right

\section{Embankment type} Slight curve

nasmintin... af ata... n fill 7/17/96 Sloping Type-3 stone-fill along upstream right bank from the bridge to 192 feet upstream. Type-2 stone-fill along the right abutment and the downstream right bank extending from the bridge to 205 feet downstream.

Abutments and wingwalls are concrete. The right abutment is impacted by flows and scour is evident along this abutment.

\section{$\mathrm{Y}$ 30}

Is bridge skewed to flood flow according to $\mathrm{Y} \quad$ ' survey? Angle

There is a moderate channel bend through the reach.,

Debris accumulation on bridge at time of Level I or Level II site visit:

$$
\begin{gathered}
\text { Date of insnortion } \\
7 / 17 / 96 \\
\hline
\end{gathered}
$$

Level I

$$
7 / 17 / 96
$$

Moderate. In the reach upstream there are roots exposed in the

Level II

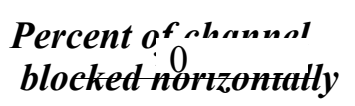
blocked inortzontatly
Percent of 0
blocked verticatty 0 channel banks and on top of the banks there are some dead trees. Potential for debris

There is a flood control dam approximately 2 miles upstream of the bridge. 


\section{Description of the Geomorphic Setting}

General topography The channel is located within a 600 foot-wide, flat to slightly irregular flood plain with moderate relief on both sides.

Geomorphic conditions at bridge site: downstream (DS), upstream (US)

Date of inspection $\quad 7 / 17 / 96$

DS left: $\quad$ Moderately sloped overbank.

DS right: $\quad$ Flood plain.

US left: $\quad$ Moderately sloped overbank.

US right: Flood plain.

\section{Description of the Channel}

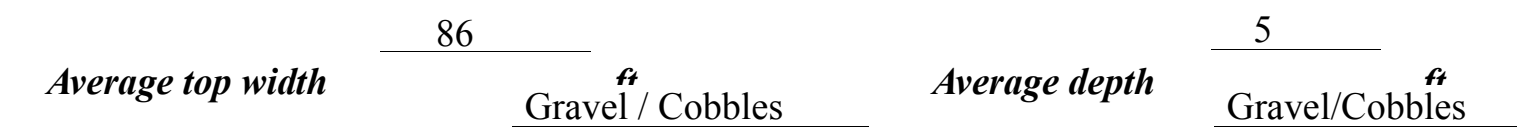

Predominant bed material

Bank material

Incised and sinuous

with alluvial channel boundaries and a narrow flood plain.

$7 / 17 / 96$

Vegetative co 1 Trees and brušh.

DS left: $\quad$ Some trees and brush on bank with lawns and buildings on overbank.

DS right: $\quad$ Trees and brush

US left: $\quad$ Some brush on bank with lawns and buildings on overbank.

US right:

No

Do banks appear stable? The reach is assessed as laterally unstable. Howeyer the impacted right bank is well protected with type-3 stone-fill upstream of the bridge and type-2 stone-fill
date of observatton. downstream.

July 17,1996 . There is a

point bar along the left third of the channel under the bridge.

Describe any obstructions in channel and date of observation. 


\section{Hydrology}

Drainage area $\stackrel{42.8}{\boldsymbol{m i}^{2}}$

Percentage of drainage area in physiographic provinces: (approximate)

Physiographic province/section New England/New England Upland
Percent of drainage area 100

Is drainage area considered rural or urban? Rural Describe any significant urbanization:

None. The stream runs through the village of East Barre just upstream of the bridge.

Is there a USGS gage on the stream of interest?

Yes

Jail Branch at East Barre

USGS gage description

04284000

USGS gage number

Gage drainage area $\frac{38.9}{\text { mi }^{2}}$

Yes

Is there a lake/p An Ärmy Corp of Engineers flood control dam is löated immediately upstream of the gage location. The capacity of the reservior is 525 million cubic feet.

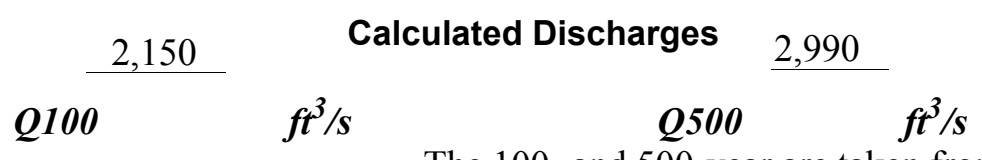

The 100- and 500-year are taken from the Flood

Insurance Study for the Town of Barre (Federal Emergency Management Agency, 1977). 


\section{Description of the Water-Surface Profile Model (WSPRO) Analysis}

Datum for WSPRO analysis (USGS survey, sea level, VTAOT plans)

USGS survey

Datum tie between USGS survey and VTAOT plans

Subtract 231.6 from the USGS

arbitrary survey datum to obtain VTAOT plans' datum.

Description of reference marks used to determine USGS datum. $\quad$ RM1 is a chiseled X on top of the upstream end of the right abutment (elev. $500.01 \mathrm{ft}$, arbitrary survey datum). RM4 is a survey disk in the upstream end of the left abutment (elev. $501.24 \mathrm{ft}$, arbitrary survey datum).

\section{Cross-Sections Used in WSPRO Analysis}

\begin{tabular}{|c|c|c|c|}
\hline${ }^{1}$ Cross-section & $\begin{array}{c}\text { Section } \\
\text { Reference } \\
\text { Distance } \\
\text { (SRD) in feet }\end{array}$ & $\begin{array}{c}{ }^{2} \text { Cross-section } \\
\text { development }\end{array}$ & Comments \\
\hline EXITX & -68 & 1 & Exit section \\
\hline FULLV & 0 & 2 & $\begin{array}{l}\text { Downstream Full-valley } \\
\text { section (Templated from } \\
\text { EXITX) }\end{array}$ \\
\hline BRIDG & 0 & 1 & Bridge section \\
\hline RDWAY & 20 & 1 & Road Grade section \\
\hline APTEM & 93 & 1 & $\begin{array}{l}\text { Approach section as sur- } \\
\text { veyed (Used as a tem- } \\
\text { plate) }\end{array}$ \\
\hline APPRO & 113 & 2 & $\begin{array}{l}\text { Modelled Approach sec- } \\
\text { tion (Templated from } \\
\text { APTEM) }\end{array}$ \\
\hline
\end{tabular}

${ }^{1}$ For location of cross-sections see plan-view sketch included with Level I field form, Appendix E. For more detail on how cross-sections were developed see WSPRO input file. 


\section{Data and Assumptions Used in WSPRO Model}

Hydraulic analyses of the reach were done by use of the Federal Highway Administration's WSPRO step-backwater computer program (Shearman and others, 1986, and Shearman, 1990). The analyses reported herein reflect conditions existing at the site at the time of the study. Furthermore, in the development of the model it was necessary to assume no accumulation of debris or ice at the site. Results of the hydraulic model are presented in the Bridge Hydraulic Summary, Appendix B, and figure 7.

Channel roughness factors (Manning's " $n$ ") used in the hydraulic model were estimated using field inspections at each cross section following the general guidelines described by Arcement and Schneider (1989). Final adjustments to the values were made during the modelling of the reach. Channel " $n$ " values for the reach ranged from 0.035 to 0.045 , and overbank " $n$ " values ranged from 0.040 to 0.055 .

Normal depth at the exit section (EXITX) was assumed as the starting water surface. This depth was computed by use of the slope-conveyance method outlined in the user's manual for WSPRO (Shearman, 1990). The slope used was $0.0083 \mathrm{ft} / \mathrm{ft}$, which is the slope of the 100year water surface profile downstream of the bridge in the Flood Insurance Study for the Town of Barre (Federal Emergency Management Agency, 1977).

The surveyed approach section (APTEM) was moved to establish the modelled approach section (APPRO), one bridge length upstream of the upstream face as recommended by Shearman and others (1986). This approach section location also provides a consistent method for determining scour variables.

For the 100- and 500-year and discharges, WSPRO assumes critical depth at the bridge section. Supercritical models were developed for these discharges. Analyzing both the supercritical and subcritical profiles for each discharge, it can be determined that the water surface profile does pass through critical depth within the bridge opening. Thus, the assumptions of critical depth at the bridge are satisfactory solutions. 


\section{Bridge Hydraulics Summary}

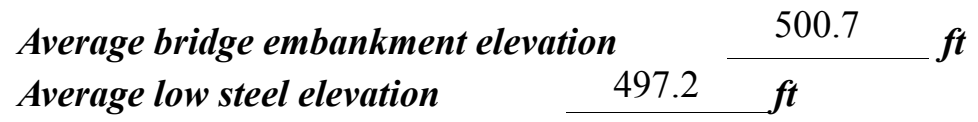

$$
\text { 100-year discharge } \quad 2,150 \quad \mathrm{ft}^{3} / \mathrm{s}
$$

Water-surface elevation in bridge opening

$492.9 \boldsymbol{f t}$

Road overtopping? ___ N Discharge over road __

Area of flow in bridge opening $\quad 218 \quad \mathrm{ft}^{2}$

Average velocity in bridge opening $\quad 9.9 \mathrm{ft} / \mathrm{s}$

$\begin{array}{llll}\text { Maximum WSPRO tube velocity at bridge } & 13.0 \mathrm{ft} / \mathrm{s}\end{array}$

Water-surface elevation at Approach section with bridge

Water-surface elevation at Approach section without bridge

494.9

Amount of backwater caused by bridge

1.1 it

500-year discharge $\quad 2,990 \quad \mathrm{ft}^{3} / \mathrm{s}$

Water-surface elevation in bridge opening

Road overtopping?

$\mathrm{N}$

Discharge over road

$493.6 \mathrm{ft}$

Area of flow in bridge opening

Average velocity in bridge opening 271 $f t^{2}$

Maximum WSPRO tube velocity at bridge $\quad 14.5$ 's $11.0 \mathrm{ft} / \mathrm{s}$

Water-surface elevation at Approach section with bridge

Water-surface elevation at Approach section without bridge

495.8

Amount of backwater caused by bridge

1.0

Incipient overtopping discharge ___ -- $f^{3} / \mathrm{s}$

Water-surface elevation in bridge opening $\quad--\quad$ it

Area of flow in bridge opening

$-f^{2}$

Average velocity in bridge opening

Maximum WSPRO tube velocity at bridge $f t^{2}$

$-f^{-} \mathrm{ft} / \mathrm{s}$

Water-surface elevation at Approach section with bridge

Water-surface elevation at Approach section without bridge

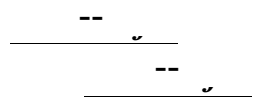
Amount of backwater caused by bridge $-\quad i$ 


\section{Scour Analysis Summary}

\section{Special Conditions or Assumptions Made in Scour Analysis}

Scour depths were computed using the general guidelines described in Hydraulic Engineering Circular 18 (Richardson and others, 1995). Scour depths were calculated assuming an infinite depth of erosive material and a homogeneous particle-size distribution. The results of the scour analysis are presented in tables 1 and 2 and a graph of the scour depths is presented in figure 8.

Contraction scour was computed by use of the clear-water contraction scour equation (Richardson and others, 1995, p. 32, equation 20). For contraction scour computations, the average depth in the contracted section (AREA/TOPWIDTH) is subtracted from the depth of flow computed by the scour equation (Y2) to determine the actual amount of scour. Armoring computations indicate that armoring will not impede contraction scour.

Abutment scour was computed by use of the Froehlich equation (Richardson and others, 1995, p. 48, equation 28). Variables for the Froehlich equation include the Froude number of the flow approaching the embankments, the length of the embankment blocking flow, and the depth of flow approaching the embankment less any roadway overtopping.

Total scour for the 100-year event, as predicted by the scour equations, does not undermine the abutment footings. 


\section{Scour Results}

\section{0-yr discharge 500-yr discharge}

Contraction scour:

(Scour depths in feet)

Main channel

Live-bed scour

Clear-water scour

Depth to armoring

Left overbank

Right overbank

Local scour:

Abutment scour

Left abutment

4.3

$5.8-$

6.2

7.5

Right abutment

Pier scour

Pier 1

Pier 2

Pier 3

\section{Abutments:}

Left abutment

Right abutment

Piers:

Pier 1

Pier 2

\section{Riprap Sizing}

Incipient overtopping 100-yr discharge 500-yrdischarge discharge

1.3

1.3

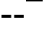

--

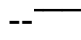
( $D_{50}$ in feet)

1.6

1.6

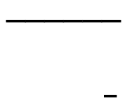
overtopping discharge

-

--

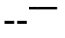




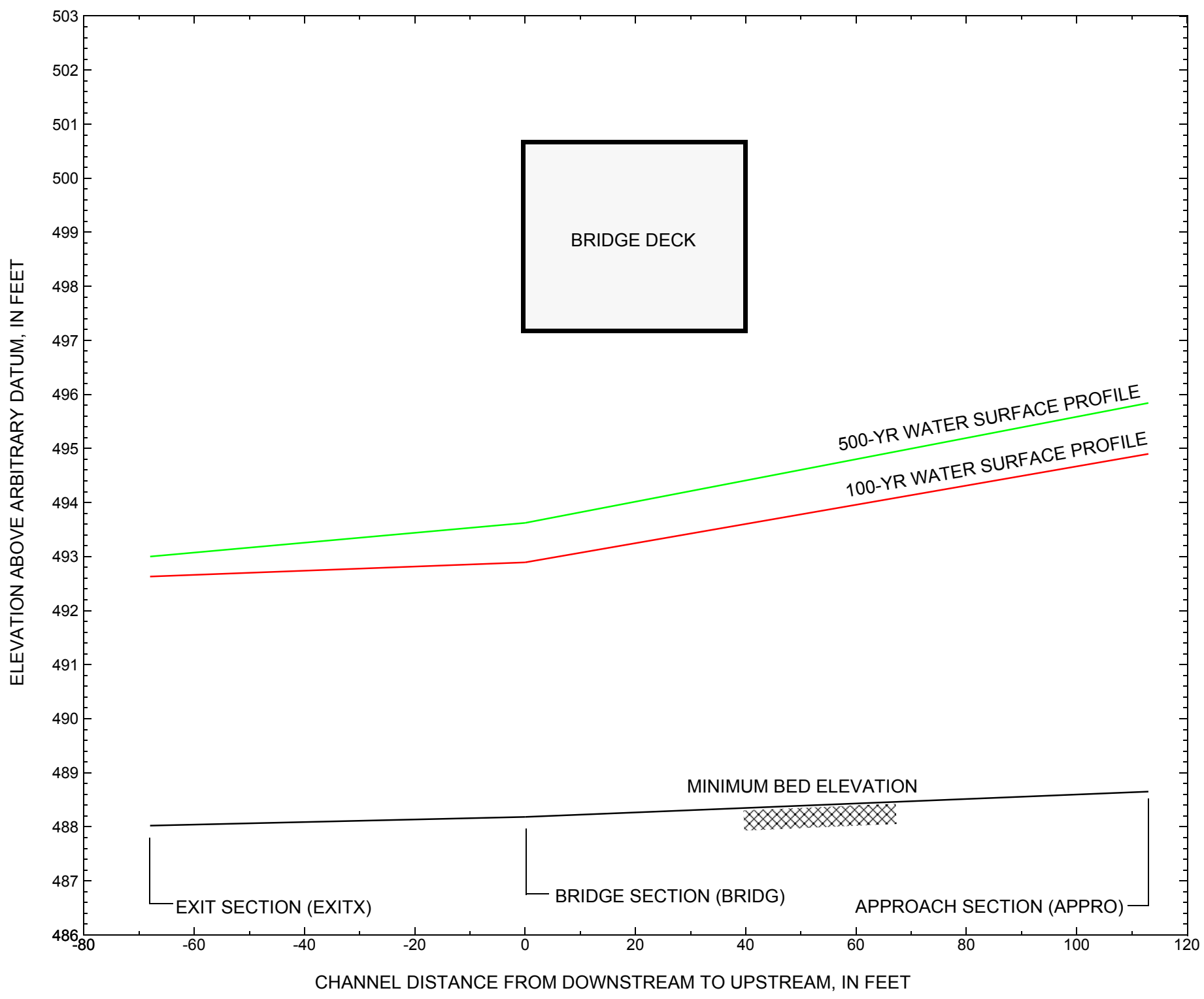

Figure 7. Water-surface profiles for the 100- and 500-yr discharges at structure BARRUS03020009 on U.S. Route 302, crossing Jail Branch, Barre, Vermont. 


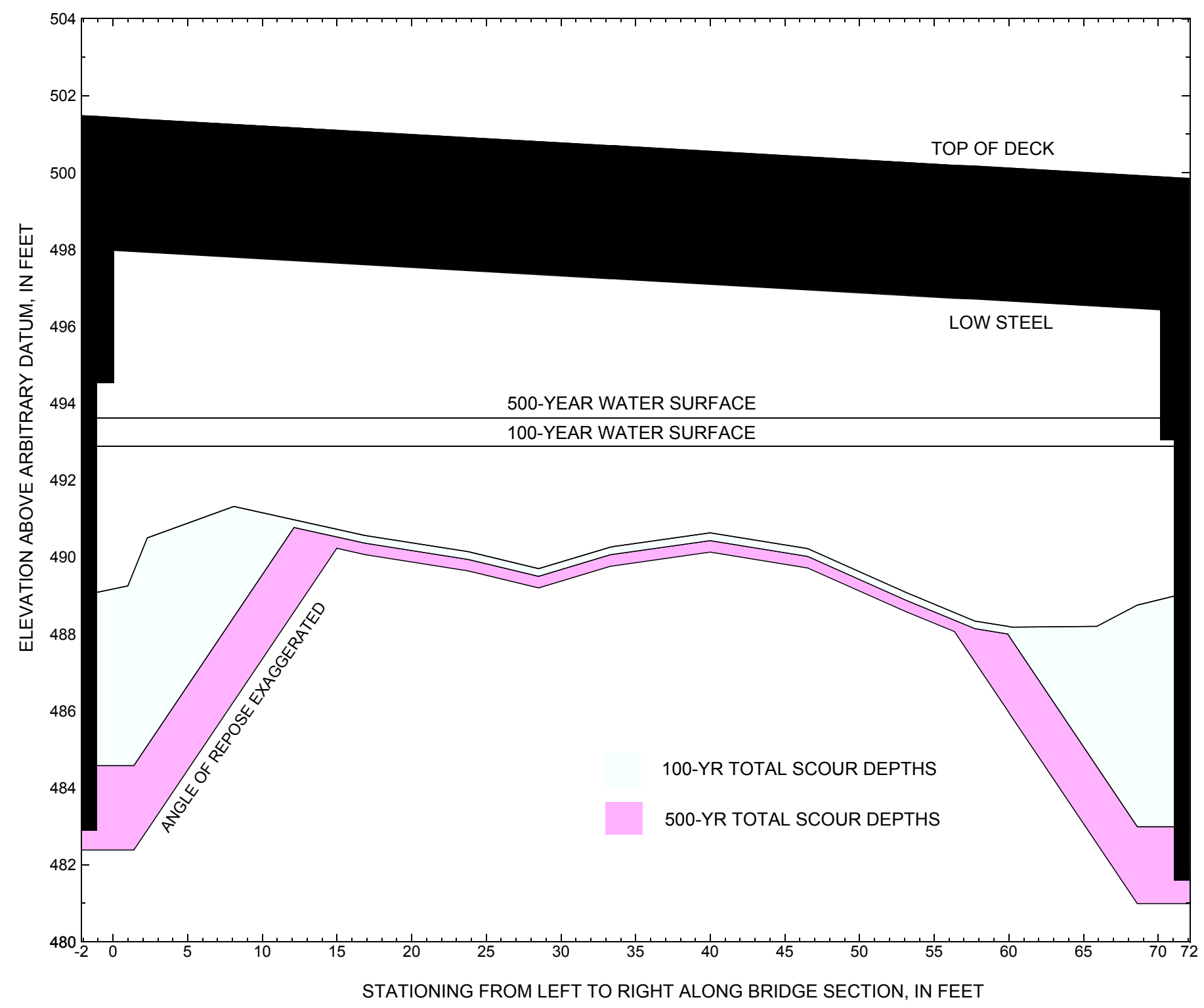

Figure 8. Scour elevations for the 100-yr and 500-yr discharges at structure BARRUS03020009 on U.S. Route 302, crossing Jail Branch, Barre, Vermont. 


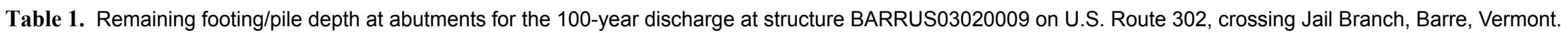
[VTAOT, Vermont Agency of Transportation; --,no data]

\begin{tabular}{|c|c|c|c|c|c|c|c|c|c|c|c|}
\hline Description & Station $^{1}$ & $\begin{array}{c}\text { VTAOT } \\
\text { bridge seat } \\
\text { elevation } \\
\text { (feet) }\end{array}$ & $\begin{array}{l}\text { Surveyed } \\
\text { minimum } \\
\text { low-chord } \\
\text { elevation } \\
\quad \text { (feet) }\end{array}$ & $\begin{array}{c}\text { Bottom of } \\
\text { footing } \\
\text { elevation } \\
\text { (feet) }\end{array}$ & $\begin{array}{c}\text { Channel } \\
\text { elevation at } \\
\text { abutment/ } \\
\text { pier }^{2} \\
\text { (feet) }\end{array}$ & $\begin{array}{l}\text { Contraction } \\
\text { scour depth } \\
\text { (feet) }\end{array}$ & $\begin{array}{l}\text { Abutment } \\
\text { scour } \\
\text { depth } \\
\text { (feet) }\end{array}$ & $\begin{array}{l}\text { Pier } \\
\text { scour } \\
\text { depth } \\
\text { (feet) }\end{array}$ & $\begin{array}{l}\text { Depth of } \\
\text { total scour } \\
\text { (feet) }\end{array}$ & $\begin{array}{c}\text { Elevation of } \\
\text { scour }^{2} \\
\text { (feet) }\end{array}$ & $\begin{array}{c}\text { Remaining } \\
\text { footing/pile } \\
\text { depth } \\
\text { (feet) }\end{array}$ \\
\hline \multicolumn{12}{|c|}{100 -yr. discharge is 2,150 cubic-feet per second } \\
\hline Left abutment & -1.1 & 266.0 & 498.0 & 482.9 & 489.1 & 0.2 & 4.3 & -- & 4.5 & 484.6 & 1.7 \\
\hline Right abutment & 71.1 & 264.6 & 496.4 & 481.6 & 489.0 & 0.2 & 5.8 & -- & 6.0 & 483.0 & 1.4 \\
\hline
\end{tabular}

1.Measured along the face of the most constricting side of the bridge.

2.Arbitrary datum for this study.

Table 2. Remaining footing/pile depth at abutments for the 500-year discharge at structure BARRUS03020009 on U.S. Route 302, crossing Jail Branch, Barre, Vermont. [VTAOT, Vermont Agency of Transportation; --, no data]

\begin{tabular}{|c|c|c|c|c|c|c|c|c|c|c|c|}
\hline Description & Station $^{1}$ & $\begin{array}{c}\text { VTAOT } \\
\text { bridge seat } \\
\text { elevation } \\
\text { (feet) }\end{array}$ & $\begin{array}{l}\text { Surveyed } \\
\text { minimum } \\
\text { low-chord } \\
\text { elevation } \\
\quad \text { (feet) }\end{array}$ & $\begin{array}{c}\text { Bottom of } \\
\text { footing } \\
\text { elevation } \\
\text { (feet) }\end{array}$ & $\begin{array}{c}\text { Channel } \\
\text { elevation at } \\
\text { abutment/ } \\
\text { pier }^{2} \\
\text { (feet) }\end{array}$ & $\begin{array}{c}\text { Contraction } \\
\text { scour depth } \\
\text { (feet) }\end{array}$ & $\begin{array}{l}\text { Abutment } \\
\text { scour } \\
\text { depth } \\
\text { (feet) }\end{array}$ & $\begin{array}{l}\text { Pier } \\
\text { scour } \\
\text { depth } \\
\text { (feet) }\end{array}$ & $\begin{array}{l}\text { Depth of } \\
\text { total scour } \\
\text { (feet) }\end{array}$ & $\begin{array}{c}\text { Elevation of } \\
\text { scour }^{2} \\
\text { (feet) }\end{array}$ & $\begin{array}{c}\text { Remaining } \\
\text { footing/pile } \\
\text { depth } \\
\text { (feet) }\end{array}$ \\
\hline \multicolumn{12}{|c|}{500 -yr. discharge is 2,990 cubic-feet per second } \\
\hline Left abutment & -1.1 & 266.0 & 498.0 & 482.9 & 489.1 & 0.5 & 6.2 & -- & 6.7 & 482.4 & -0.5 \\
\hline Right abutment & 71.1 & 264.6 & 496.4 & 481.6 & 489.0 & 0.5 & 7.5 & -- & 8.0 & 481.0 & -0.6 \\
\hline
\end{tabular}

1.Measured along the face of the most constricting side of the bridge.

2.Arbitrary datum for this study. 


\section{SELECTED REFERENCES}

Arcement, G.J., Jr., and Schneider, V.R., 1989, Guide for selecting Manning's roughness coefficients for natural channels and flood plains: U.S. Geological Survey Water-Supply Paper 2339, 38 p.

Barnes, H.H., Jr., 1967, Roughness characteristics of natural channels: U.S. Geological Survey Water-Supply Paper 1849,213 p.

Benson, M. A., 1962, Factors Influencing the Occurrence of Floods in a Humid Region of Diverse Terrain: U.S. Geological Survey WaterSupply Paper 1580-B, 64 p.

Brown, S.A. and Clyde, E.S., 1989, Design of riprap revetment: Federal Highway Administration Hydraulic Engineering Circular No. 11, Publication FHWA-IP-89-016, 156 p.

Federal Highway Administration, 1983, Runoff estimates for small watersheds and development of sound design: Federal Highway Administration Report FHWA-RD-77-158

Federal Emergency Management Agency, 1977, Flood Insurance Study, Town of Barre, Washington County, Vermont: Washington, D.C., December 1977.

Froehlich, D.C., 1989, Local scour at bridge abutments in Ports, M.A., ed., Hydraulic Engineering--Proceedings of the 1989 National Conference on Hydraulic Engineering: New York, American Society of Civil Engineers, p. 13-18.

Hayes, D.C.,1993, Site selection and collection of bridge-scour data in Delaware, Maryland, and Virginia: U.S. Geological Survey WaterResources Investigation Report 93-4017, 23 p.

Interagency Advisory Committee on Water Data, 1982, Guidelines for determining flood flow frequency: U.S. Geological Survey, Bulletin 17B of the Hydrology Subcommittee, 190 p.

Johnson, C.G. and Tasker, G.D.,1974, Progress report on flood magnitude and frequency of Vermont streams: U.S. Geological Survey OpenFile Report 74-130, 37 p.

Lagasse, P.F., Schall, J.D., Johnson, F., Richardson, E.V., Chang, F., 1995, Stream Stability at Highway Structures: Federal Highway Administration Hydraulic Engineering Circular No. 20, Publication FHWA-IP-90-014, 144 p.

Laursen, E.M., 1960, Scour at bridge crossings: Journal of the Hydraulics Division, American Society of Civil Engineers, v. 86, no. HY2, p. 39-53.

Potter, W. D., 1957a, Peak rates of runoff in the Adirondack, White Mountains, and Maine woods area, Bureau of Public Roads

Potter, W. D., 1957b, Peak rates of runoff in the New England Hill and Lowland area, Bureau of Public Roads

Richardson, E.V. and Davis, S.R., 1995, Evaluating scour at bridges: Federal Highway Administration Hydraulic Engineering Circular No. 18, Publication FHWA-IP-90-017, 204 p.

Richardson, E.V., Simons, D.B., and Julien, P.Y., 1990, Highways in the river environment: Federal Highway Administration Publication FHWA-HI-90-016.

Ritter, D.F., 1984, Process Geomorphology: W.C. Brown Co., Debuque, Iowa, 603 p.

Shearman, J.O., 1990, User's manual for WSPRO--a computer model for water surface profile computations: Federal Highway Administration Publication FHWA-IP-89-027, 187 p.

Shearman, J.O., Kirby, W.H., Schneider, V.R., and Flippo, H.N., 1986, Bridge waterways analysis model; research report: Federal Highway Administration Publication FHWA-RD-86-108, 112 p.

Talbot, A.N., 1887, The determination of water-way for bridges and culverts.

U.S. Department of Transportation, 1993, Stream stability and scour at highway bridges, Participant Workbook: Federal Highway Administration Publication FHWA HI-91-011.

U.S. Geological Survey, 1981, Barre East, Vermont 7.5 Minute Series quadrangle map: U.S. Geological Survey Topographic Maps, Scale $1: 24,000$. 


\section{APPENDIX A: \\ WSPRO INPUT FILE}




\section{WSPRO INPUT FILE}

$\mathrm{XR}$

GR

GR

GR

GR

$\mathrm{XT}$

GR

GR

GR

GR

GR

GR

*

AS

$\mathrm{N}$

SA

*

HP 1 BRIDG

HP 2 BRIDG

HP 1 APPRO

HP 2 APPRO

*

HP 1 BRIDG

FULLV

BRIDG

APPRO
U.S. Geological Survey WSPRO Input File barro09.wsp Hydraulic analysis for structure BARRUS03020009 Date: 05-DEC-96 BARRE BRIDGE \#9 OVER JAIL BRANCH SAO

$\begin{array}{lllllllllllllllllllll}6 & 29 & 30 & 552 & 553 & 551 & 5 & 16 & 17 & 13 & 3 & * & 15 & 14 & 23 & 21 & 11 & 12 & 4 & 7 & 3\end{array}$

21502990

$0.0083 \quad 0.0083$

$\operatorname{EXITX}-68$

$-72.6,502.20$

$-33.0,489.65$

$-30.9,489.03$

$-23.7,489.02$

$-11.0,490.18$

$-22.4,488.59$

$-21.2,488.99$

$-16.4,489.83$

$20.6,488.02$

$-2.4,489.45$

$26.0,488.54$

$29.2,489.70$

$11.3,488.60$

$42.6,494.05$

$515.7,492.17$

$162.3,493.06$

$292.2,492.81 \quad 461.2,491.68$

$733.1,506.16$

$556.0,491.83$

$695.7,492.00 \quad 715.1,504.07$

0.040

$-72.6$

42.6

$0 * \star \star 0.0021$

$0 \quad 497.21$

$-1.1,494.56$

$-0.8,489.08$

$1.0,489.25$

$23.8,490.14$

$2.3,490.50$

$28.5,489.70$

$46.5,490.22$

$53.1,489.08$

$33.3,490.26$

$40.0,490.63$

$65.9,488.20$

$68.6,488.75$

$71.1,488.99$

$60.2,488.18$

$70.3,493.13$

$70.3,496.41$

$0.0,498.00$

$0.0,494.70$

$-1.1,494.56$

0.035

150.6 * *

45.0

9.7

RDWAY $20 \quad 39$

$-374.5,505.36$

$2.0,502.18$

$-236.6,504.42$

$72.4,500.96$

$125.4,499.19$

$192.6,497.60$

$567.3,503.26$

$647.1,512.38$

$0.0,501.36$

$0.3, \quad 502.19$

$74.3,500.92$

$74.5,499.96$

$494.8,493.77$

$527.3,493.80$

APTEM 93

$-59.6,501.98$

$-34.1,500.53$

$-25.2,496.80$

$-2.1,492.54$

$10.7,489.86$

$26.0,489.22$

$42.0,489.52$

$87.7,495.58$

$44.1,489.53$

$40.4,488.91$

$50.4,492.93$

$44.6,491.03$

$238.0,498.09$

$348.6,497.14$

$136.2,497.81$

$527.3,497.20$
$567.3,503.26$

113

0.0

0.055

$-34.1$

0.039

50.4

0.040

492.891492 .89

492.89 * * 2150

494.901494 .90

494.90 * 2150

$493.62 \quad 1 \quad 493.62$ 


\section{APPENDIX B: \\ WSPRO OUTPUT FILE}


WSPRO OUTPUT FILE

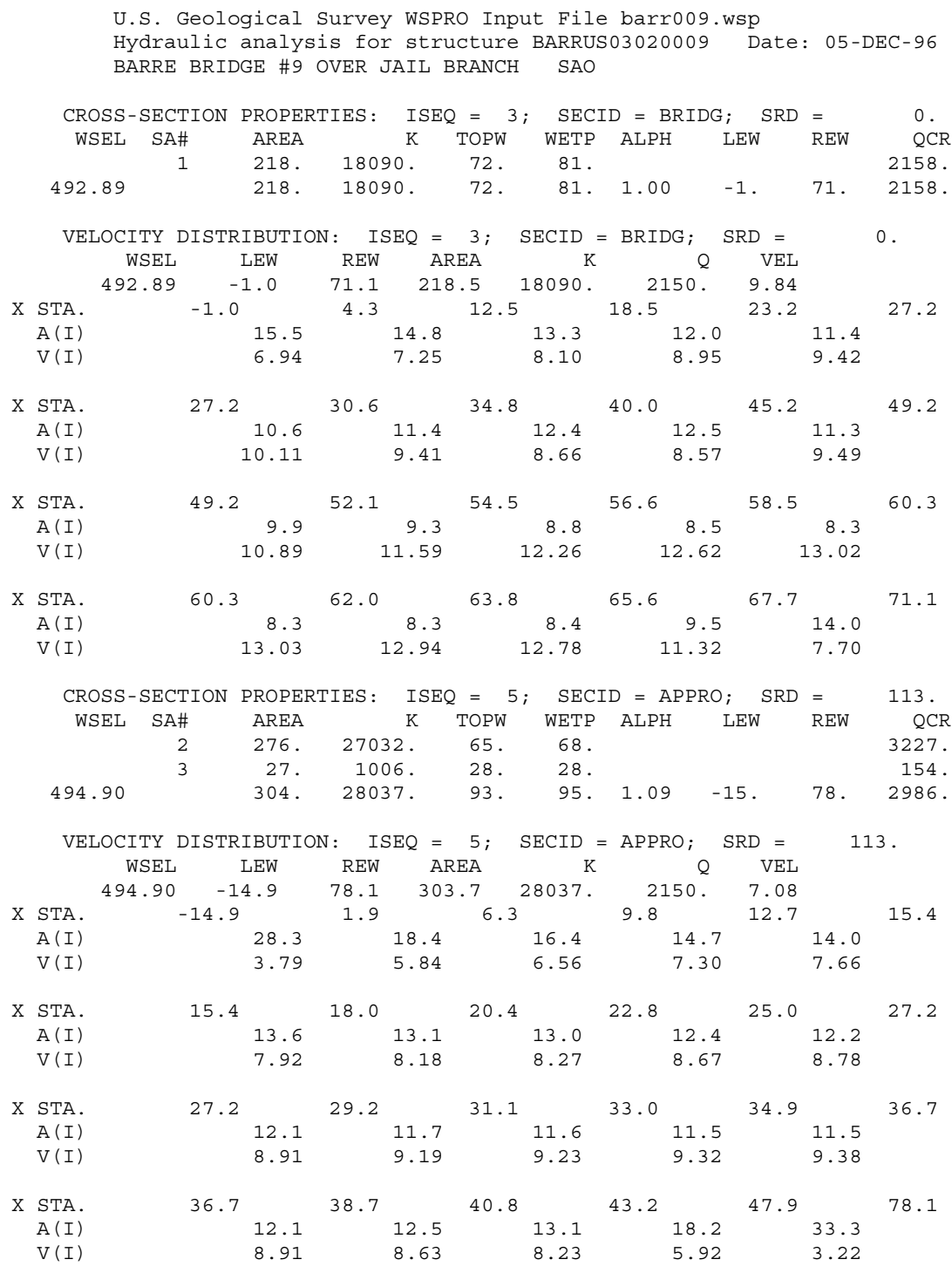


WSPRO OUTPUT FILE (continued)

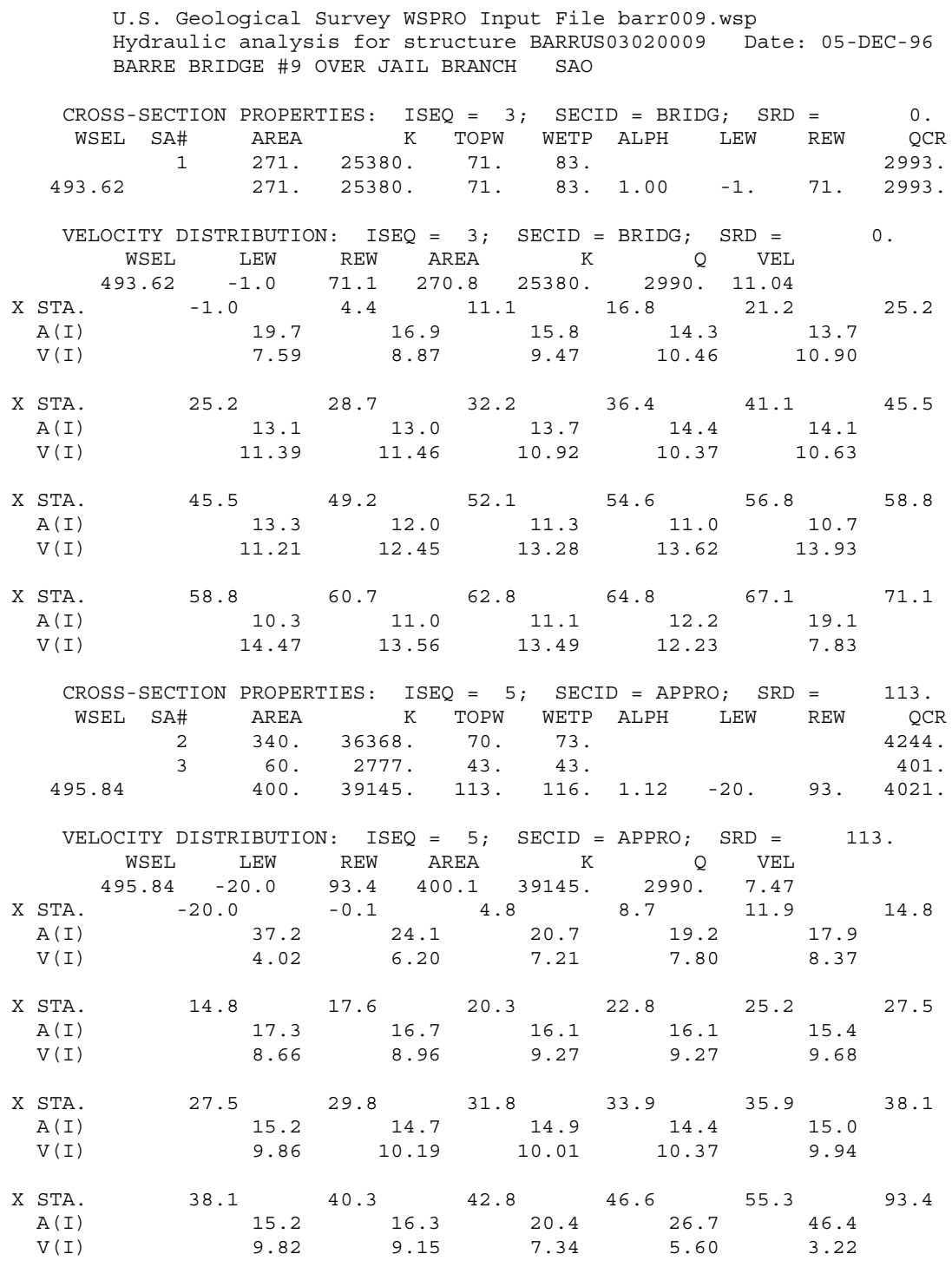


WSPRO OUTPUT FILE (continued)

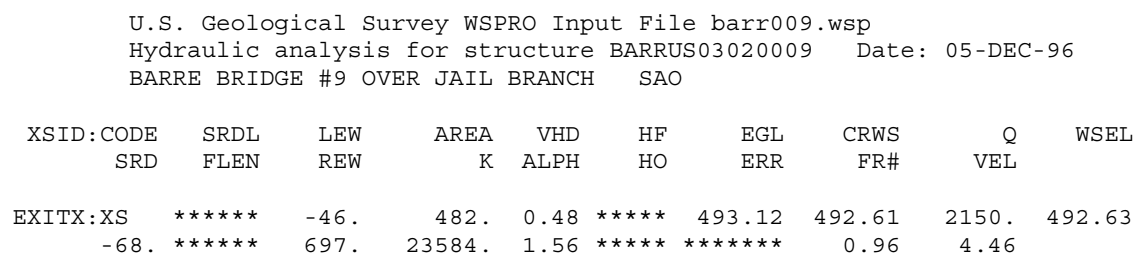

$===135$ CONVEYANCE RATIO OUTSIDE OF RECOMMENDED LIMITS.

"FULLV" KRATIO $=1.55$
FULLV : FV 68. $\quad$ 6 $47 . \quad 741.0 .20 \quad 0.36 \quad 493.47 * * * * * * * \quad 2150.493 .26$

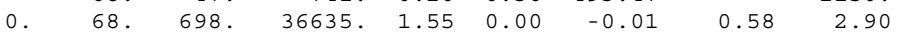 $<<<<$ THE ABOVE RESULTS REFLECT "NORMAL" (UNCONSTRICTED) FLOW >>>>>

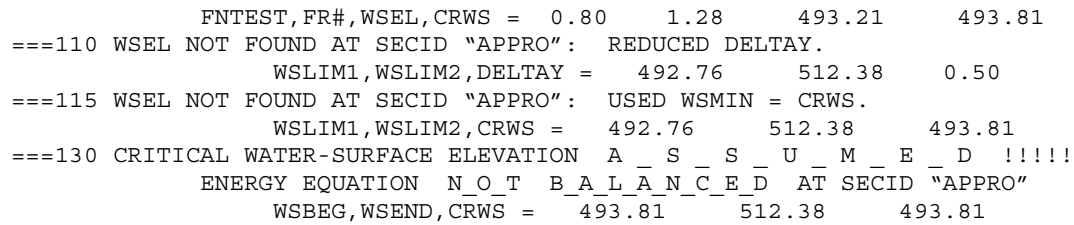


WSPRO OUTPUT FILE (continued)

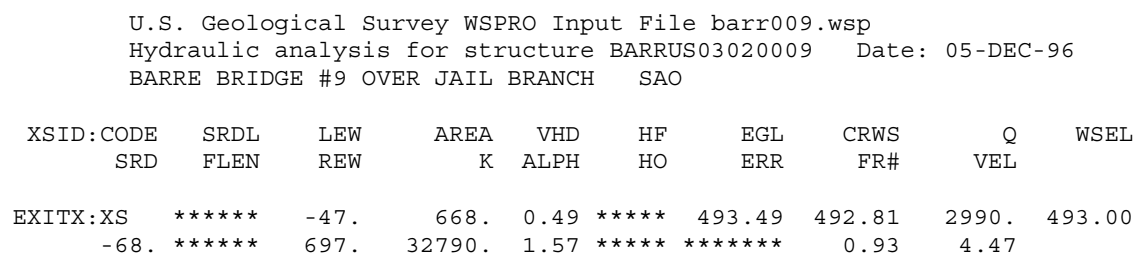

$==135$ CONVEYANCE RATIO OUTSIDE OF RECOMMENDED LIMITS.

"FULLV" KRATIO $=1.58$

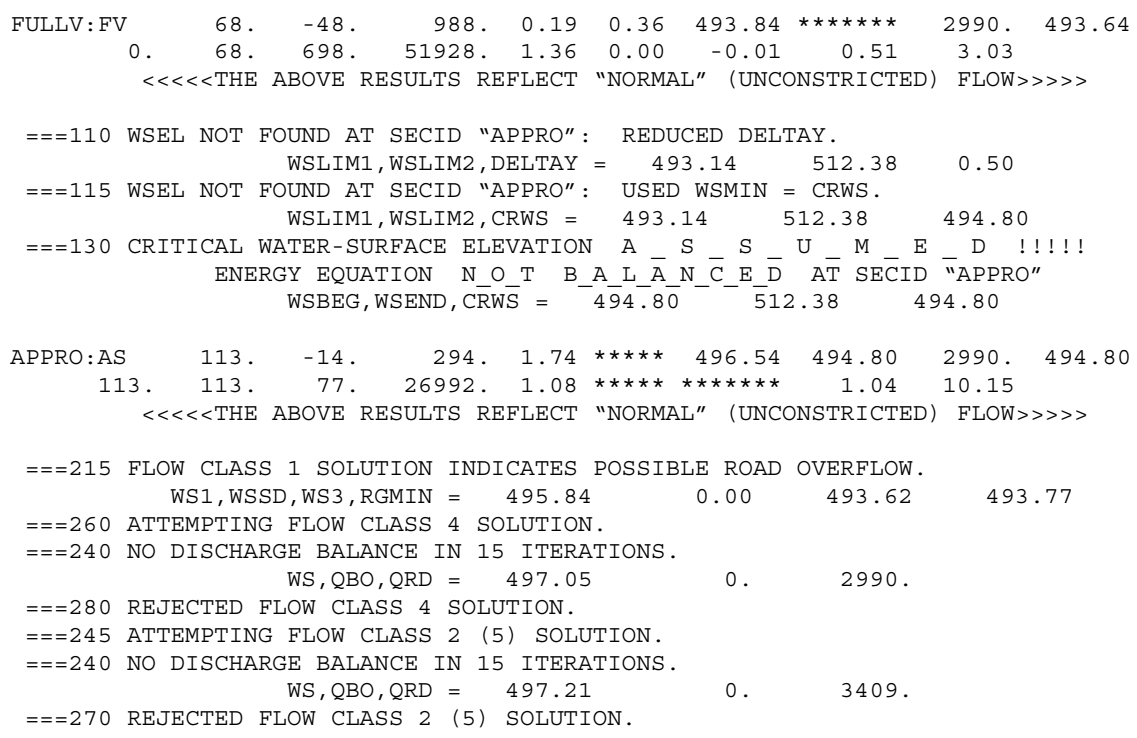




\section{APPENDIX C:}

\section{BED-MATERIAL PARTICAL-SIZE DISTRIBUTION}




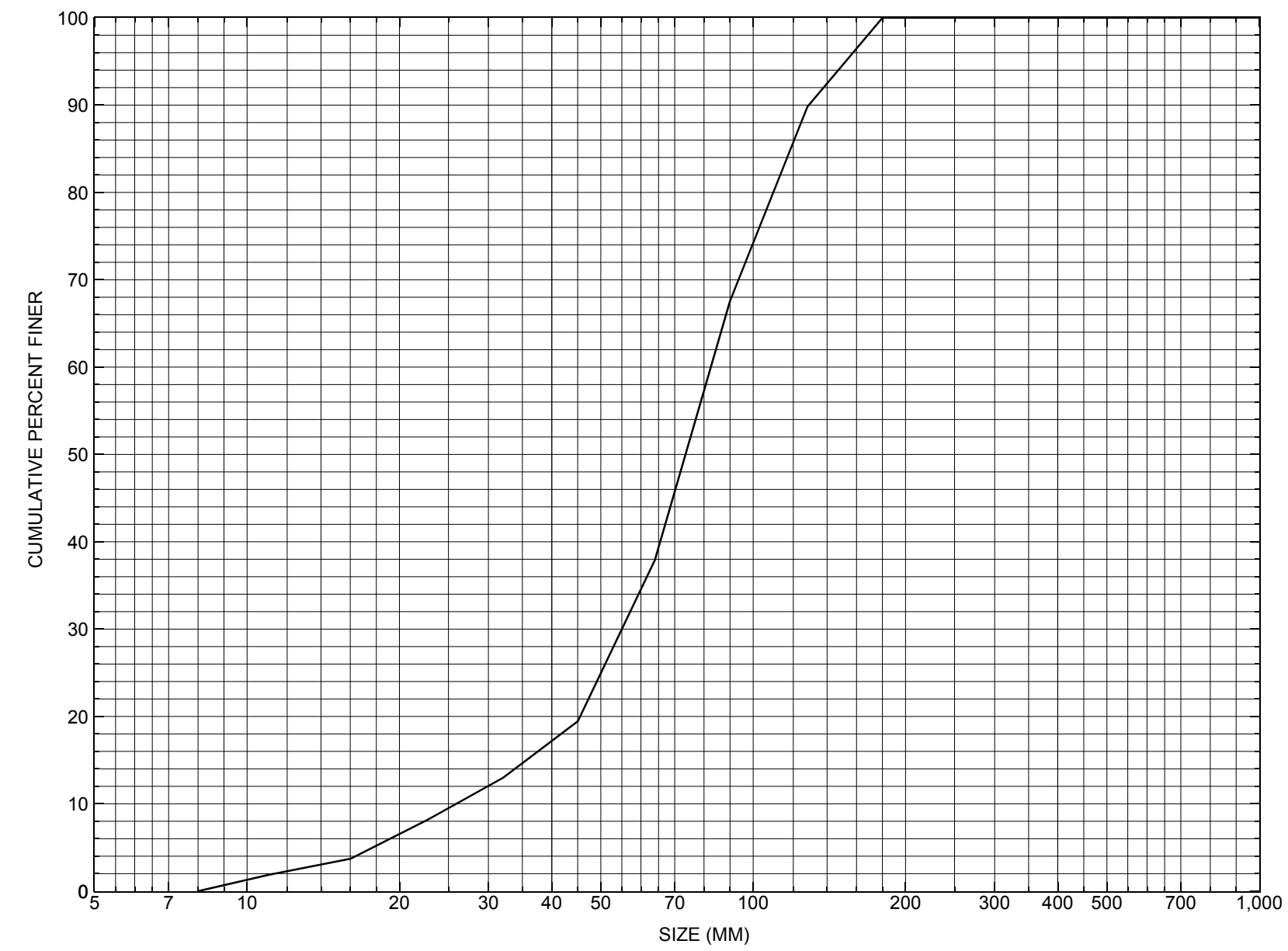

Appendix C. Bed material particle-size distribution for a pebble count in the channel approach of structure BARRUS03020009, in Barre, Vermont. 


\section{APPENDIX D: \\ HISTORICAL DATA FORM}




\section{Structure Number BARRUS03020009}

\section{General Location Descriptive}

Data collected by (First Initial, Full last name) $\underline{\text { L. }}$. Medalie

Date $(M M / D D / Y Y) \_10 / 13 / \underline{95}$

Highway District Number (I - 2; nn) $\mathbf{0 6}$

Town (FIPS place code; I - 4; nnnnn) $\mathbf{0 3 2 5 0}$

Waterway (I - 6) JAIL BRANCH BROOK

Route Number US 302

Topographic Map Barre East

Latitude (I - 16; nnnn.n) $\mathbf{4 4 1 0 6}$
County (FIPS county code; I - 3; nnn)

Mile marker (I - 11; nnn.nnn) $\mathbf{0 0 1 0 5 0}$

Road Name (I - 7):

Vicinity (I - 9) 1.5 MI W JCT. 110

Hydrologic Unit Code: 2010003

Longitude (i - 17; nnnnn.n) $\mathbf{7 2 2 8 0}$

\section{Select Federal Inventory Codes}

FHWA Structure Number (I - 8) $\mathbf{2 0 0 0 2 6 0 0 0 9 1 2 0 2}$

Maintenance responsibility $(I-21 ; n n) \quad 01$

Year built (I - 27; YYYY) 1928

Average daily traffic, ADT (I - 29; nnnnnn) 006280

Year of ADT (I - 30; YY) $\mathbf{9 2}$

Opening skew to Roadway $(I-34 ; n n) \quad \mathbf{0 0}$

Operational status $(I-41 ; X) \underline{\mathbf{A}}$

Structure type (I - 43; nnn) $\mathbf{3 0 2}$

Approach span structure type (I - 44; nnn) $\mathbf{0 0 0}$

Number of spans (I - 45; nnn) $\mathbf{0 0 1}$

Number of approach spans (I - 46; nnnn) $\mathbf{0 0 0 0}$

Comments:

According to the structural inspection report dated 8/2/93, the structure is a single-span rolled-beam bridge. The channel takes a minor turn into the structure and is flowing along the right side. There is a sand and stone point bar along the left side of the channel. There is heavy stone fill on the right banks, US and DS. Abutment footings are not exposed. Minor channel scour is noted along right side. Minor embankment erosion is noted. Overall structure is in good condition. There are minor cracks, scaling and spalling of the abutments and wingwalls.
Maximum span length (I - 48; nnnn) $\underline{\mathbf{0 0 7 2}}$

Structure length (I - 49; nnnnnn) $\underline{\mathbf{0 0 0 0 7 4}}$

Deck Width (I - 52; nn.n) $\mathbf{3 9 0}$

Channel \& Protection $(I-61 ; n) \underline{6}$

Waterway adequacy $(I-71 ; n) \underline{5}$

Underwater Inspection Frequency $(I-92 B ; X Y Y) \_$N

Year Reconstructed (I - 106) 1972

Clear span (nnn.n ft) $\mathbf{6 9 . 1 7}$

Vertical clearance from streambed (nnn.n ft) $\underline{8}$

Waterway of full opening $\left(n n n . n \mathrm{ft}^{2}\right) \quad \mathbf{5 5 3 . 4}$ 


\section{Bridge Hydrologic Data}

Is there hydrologic data available? $\underline{\mathbf{Y}}$ if No, type ctrl-n $h \quad$ VTAOT Drainage area $\left(\mathrm{mi}^{2}\right)^{2}$ :

Terrain character:

Stream character \& type: -

Streambed material:

Discharge Data (cfs):

$$
\mathrm{Q}_{2.33} \frac{-}{\mathbf{1 6 7 0}}
$$

$\mathrm{Q}_{10}$

$\mathrm{Q}_{25} \lcm{1490}$

$\mathrm{Q}_{500}$

Record flood date $(M M / D D / Y Y): \underline{11} / \underline{4} / 27 \quad$ Water surface elevation (ft): 266.3

Estimated Discharge (cfs): Velocity at $Q$ $(\mathrm{ft} / \mathrm{s}):$

Ice conditions (Heavy, Moderate, Light) : Debris (Heavy, Moderate, Light):

The stage increases to maximum highwater elevation (Rapidly, Not rapidly):

The stream response is (Flashy, Not flashy):

Describe any significant site conditions upstream or downstream that may influence the stream's stage: 38.8 square miles of the drainage area are controlled by the East Barre Dam.

Watershed storage area (in percent):

The watershed storage area is: - (1-mainly at the headwaters; 2- uniformly distributed; 3-immediatly upstream oi the site)

Water Surface Elevation Estimates for Existing Structure:

\begin{tabular}{|c|c|c|c|c|c|}
\hline $\begin{array}{l}\text { Peak discharge frequency } \\
\text { Water surface elevation (ft)) } \\
\text { Velocity ( } f t / \mathrm{sec})\end{array}$ & $\mathrm{Q}_{2.33}$ & $Q_{10}$ & $\mathrm{Q}_{25}$ & $\begin{array}{l}Q_{50} \\
\mathbf{2 6 2}\end{array}$ & $Q_{100}$ \\
\hline
\end{tabular}

Long term stream bed changes:

Is the roadway overtopped below the $Q_{100}$ ? (Yes, No, Unknown):

Frequency:

Relief Elevation $(f t)$ :

Discharge over roadway at $\mathrm{Q}_{100}\left(f^{3} / \mathrm{sec}\right)$ :

Are there other structures nearby? (Yes, No, Unknown): Upstream distance (miles): Town: If No or Unknown, type ctrl-n os

Highway No. : Structure No. : Year Built:

Clear span $(f t)$ : Clear Height (ft): Structure Type: Full Waterway $\left(f^{2}\right)$ : 
Downstream distance (miles): Town: Year Built:

Highway No. : Structure No. : Structure Type:

Clear span $(f t)$ : Clear Height (ft): Full Waterway $\left(f^{2}\right)$ :

Comments:

\section{USGS Watershed Data}

Watershed Hydrographic Data

Drainage area (DA) $4 \mathbf{4 2 . 8} \mathrm{mi}^{2}$

Watershed storage (ST) 3.85

Bridge site elevation 780

Main channel length

11.42 $\mathrm{mi}^{2}$ Lake and pond area

1.65 $\mathrm{mi}^{2}$ $10 \%$ channel length elevation $\mathbf{9 4 0}$ $\%$

Headwater elevation 2267 $\mathrm{ft}$ $\mathrm{mi}$

Main channel slope $(S)$

(S) 66.55 $\mathrm{ft} / \mathrm{mi}$

Watershed Precipitation Data

Average site precipitation in

Average headwater precipitation in

Maximum 2yr-24hr precipitation event $(124,2)$ in

Average seasonal snowfall (Sn) $\mathrm{ft}$ 


\section{Bridge Plan Data}

Are plans available? $\mathbf{Y}$ If no, type ctrl-n pl

Project Number BP-026-1-7101

Minimum channel bed elevation: 256

Low superstructure elevation: USLAB $\mathbf{2 6 5 . 9 8}$

DSLAB 265.98 USRAB $\mathbf{2 6 4 . 5 9}$

DSRAB 264.59

Benchmark location description:

BM \#1 A, Power Pole elev. 267.32, approx. 60' upstream and 60' to right of the bridge

BM \#1, Nickel Monel Nail at corner of the upstream right abutment, elev. 268.31

BM \#1B, 24" Pine elev. 263.97, approx. 20' downstream and 120' to right of bridge

BM \#1C, Power Pole elev. 273.67 approx. 20' from west side of U.S. Rte 302 and 300' to left of bridge

Reference Point (MSL, Arbitrary, Other): Unknown Datum (NAD27, NAD83, Other):

Foundation Type: 1 (1-Spreadfooting; 2-Pile; 3- Gravity; 4-Unknown)

If 1: Footing Thickness $\mathbf{2}$ Footing bottom elevation: $\mathbf{2 5 0 * *}$

If 2: Pile Type: ___ (1-Wood; 2-Steel or metal; 3-Concrete) Approximate pile driven length:

If 3: Footing bottom elevation:

Is boring information available? $\mathbf{N}$ If no, type ctrl-n bi Number of borings taken:

Foundation Material Type: (1-regolith, 2-bedrock, 3-unknown)

Briefly describe material at foundation bottom elevation or around piles:

\section{Comments:}

**Footing bottom elev of right abutment is $\mathbf{2 5 0 . 0 0}$ feet; left abutment is 251.25 feet. The low superstructure elevations are the bridge seat elevations from the bridge plans. The US right abutment-wingwall top corner elevation is $\mathbf{2 6 8 . 4 2}$ feet, the US left abutment-wingwall top coner elevation is 269.69 feet. 


\section{Cross-sectional Data}

Is cross-sectional data available? $\underline{\mathbf{N}}$ If no, type ctrl-n xs

Source (FEMA, VTAOT, Other)? --

Comments: --

\begin{tabular}{|c|c|c|c|c|c|c|c|c|c|c|c|}
\hline Station & - & - & -- & -- & - & -- & -- & -- & - & -- & -- \\
\hline Feature & -- & -- & -- & -- & - & -- & -- & -- & - & -- & -- \\
\hline $\begin{array}{l}\text { Low cord } \\
\text { elevation }\end{array}$ & -- & - & -- & -- & - & -- & -- & -- & - & -- & -- \\
\hline $\begin{array}{l}\text { Bed } \\
\text { elevation }\end{array}$ & -- & -- & -- & -- & - & -- & -- & -- & - & -- & -- \\
\hline $\begin{array}{l}\text { Low cord to } \\
\text { bed length }\end{array}$ & -- & -- & -- & -- & - & -- & -- & -- & - & -- & -- \\
\hline Station & -- & -- & -- & -- & - & -- & -- & -- & -- & -- & -- \\
\hline Feature & - & - & -- & -- & - & -- & -- & -- & -- & -- & -- \\
\hline $\begin{array}{l}\text { Low cord } \\
\text { elevation }\end{array}$ & -- & -- & -- & -- & - & -- & -- & -- & - & -- & -- \\
\hline $\begin{array}{l}\text { Bed } \\
\text { elevation }\end{array}$ & -- & -- & -- & -- & -- & -- & -- & -- & -- & -- & -- \\
\hline $\begin{array}{l}\text { Low cord to } \\
\text { bed length }\end{array}$ & -- & -- & -- & -- & -- & -- & -- & -- & - & -- & -- \\
\hline
\end{tabular}

Source (FEMA, VTAOT, Other)?

Comments: --

\begin{tabular}{|c|c|c|c|c|c|c|c|c|c|c|c|}
\hline Station & -- & -- & -- & -- & -- & -- & -- & -- & -- & -- & -- \\
\hline Feature & -- & -- & -- & - & -- & -- & -- & -- & -- & -- & -- \\
\hline $\begin{array}{l}\text { Low cord } \\
\text { elevation }\end{array}$ & -- & -- & -- & -- & -- & -- & -- & -- & -- & -- & -- \\
\hline $\begin{array}{l}\text { Bed } \\
\text { elevation }\end{array}$ & -- & -- & -- & -- & -- & -- & -- & -- & -- & -- & -- \\
\hline $\begin{array}{l}\text { Low cord to } \\
\text { bed length }\end{array}$ & -- & -- & -- & -- & -- & -- & -- & -- & -- & -- & -- \\
\hline Station & -- & -- & -- & -- & -- & -- & -- & -- & -- & -- & -- \\
\hline Feature & -- & -- & -- & -- & -- & -- & -- & -- & -- & -- & -- \\
\hline $\begin{array}{l}\text { Low cord } \\
\text { elevation }\end{array}$ & -- & -- & -- & -- & -- & -- & -- & -- & -- & -- & -- \\
\hline $\begin{array}{l}\text { Bed } \\
\text { elevation }\end{array}$ & -- & -- & -- & -- & -- & - & -- & - & - & -- & - \\
\hline $\begin{array}{l}\text { Low cord to } \\
\text { bed length }\end{array}$ & -- & -- & -- & -- & -- & -- & -- & - & - & -- & -- \\
\hline
\end{tabular}




\section{APPENDIX E: \\ LEVEL I DATA FORM}


U. S. Geological Survey

Bridge Field Data Collection and Processing Form

Qa/Qc Check by: $\mathbf{R B}$ Date: $11 / 01 / 96$

\section{Structure Number}

BARRUS03020009

Computerized by: $\underline{\mathbf{R B}}$ Date: $11 / 05 / 96$

Reviewd by: SAO Date: $\underline{1 / 17 / 97}$

\section{A. General Location Descriptive}

1. Data collected by (First Initial, Full last name) M. IVANOFF

2. Highway District Number 06

County WASHINGTON 023

Waterway (l - 6) JAIL BRANCH BROOK

Route Number US 302

Mile marker $\mathbf{0 0 1 0 5 0}$

Town BARRE 03250

Road Name US 302

3. Descriptive comments:

Hydrologic Unit Code: 2010003

Located 1.5 miles from the junction with VT110.

\section{B. Bridge Deck Observations}
4. Surface cover... LBUS 5
RBUS 5
LBDS 6
RBDS 2
Overall 5

(2b us, ds,lb,rb: 1- Urban; 2- Suburban; 3- Row crops; 4- Pasture; 5- Shrub- and brushland; 6- Forest; 7- Wetland)
5. Ambient water surface... US 2
UB 2
DS 2
(1- pool; 2- riffle)

6. Bridge structure type 1 (1- single span; 2- multiple span; 3- single arch; 4- multiple arch; 5-cylindrical culvert; 6- box culvert; or 7- other)

7. Bridge length $\mathbf{7 4}$

(feet)

Span length $\mathbf{7 2}$

(feet)

Bridge width 39

(feet)

\section{Road approach to bridge:}
8. LB 2 RB 1
( 0 even, 1- lower, 2- higher)
9. $\mathrm{LB}$
RB 1
(1-Paved, 2- Not paved)

10. Embankment slope (run / rise in feet / foot)

US left

US right

\begin{tabular}{|c|c|c|c|}
\hline \multicolumn{2}{|c|}{ Protection } & \multirow{2}{*}{ 13.Erosion } & 14.Severity \\
\hline 11.Type & 12.Cond. & & \\
\hline $\mathbf{0}$ & - & $\mathbf{0}$ & - \\
\hline
\end{tabular}

LBUS

RBUS

RBDS

LBDS

\begin{tabular}{l|l}
\hline $\mathbf{0}$ & - \\
\hline $\mathbf{0}$ & - \\
\hline $\mathbf{0}$ & - \\
\hline
\end{tabular}

\begin{tabular}{l|l}
\hline $\mathbf{0}$ & - \\
\hline $\mathbf{0}$ & - \\
\hline $\mathbf{0}$ & - \\
\hline
\end{tabular}

Bank protection types: 0 - none; 1- $<12$ inches;

2- < 36 inches; 3- $<48$ inches;

4- < 60 inches; 5- wall / artificial levee

Bank protection conditions: 1- good; 2- slumped;

3- eroded; 4- failed

Erosion: 0 - none; 1- channel erosion; 2 -

road wash; 3- both; 4- other

Erosion Severity: 0 - none; 1- slight; 2- moderate; 3- severe

\section{Channel approach to bridge (BF):}

15. Angle of approach: $\mathbf{4 0}$

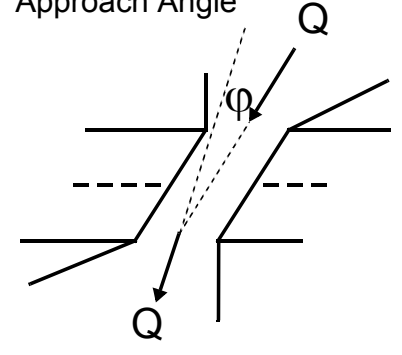

17. Channel impact zone 1 :

Where? RB (LB, RB)

Range? 70 feet $\underline{\text { US }}$

Channel impact zone 2:

Where? _ _ $(L B, R B)$

Range? - $\quad$ feet -

(US, UB, DS) to feet Impact Severity: 0- none to very slight; 1- Slight; 2- Moderate; 3- Severe

16. Bridge skew: $\mathbf{3 0}$ Bridge Skew Angle

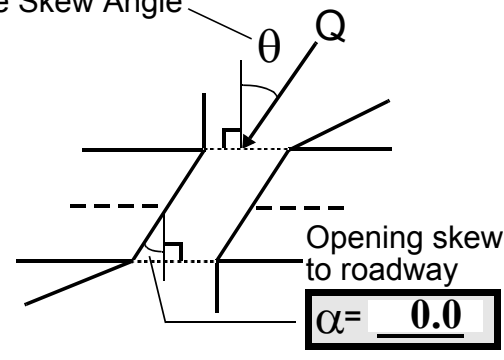

\section{Exist? $\mathbf{Y}(Y$ or $N)$}

Severity 2

(US, UB, DS) to $\underline{\mathbf{1 0 0}}$ feet $\underline{\mathbf{D S}}$

Exist? $\mathbf{N} \quad($ Yor $N)$

Severity - 
18. Bridge Type: 1a

1a- Vertical abutments with wingwalls

1 b- Vertical abutments without wingwalls

2- Vertical abutments and wingwalls, sloping embankment Wingwalls perpendicular to abut. face

3- Spill through abutments

4- Sloping embankment, vertical wingwalls and abutments

Wingwall angle less than $90^{\circ}$.

19. Bridge Deck Comments (surface cover variations, measured bridge and span lengths, bridge type variations, approach overflow width, etc.)

7. Values are from the VT AOT files. Measured bridge dimensions are the same.

4. There is a house on the right bank US beyond the trees along the immediate bank.

\section{Upstream Channel Assessment}

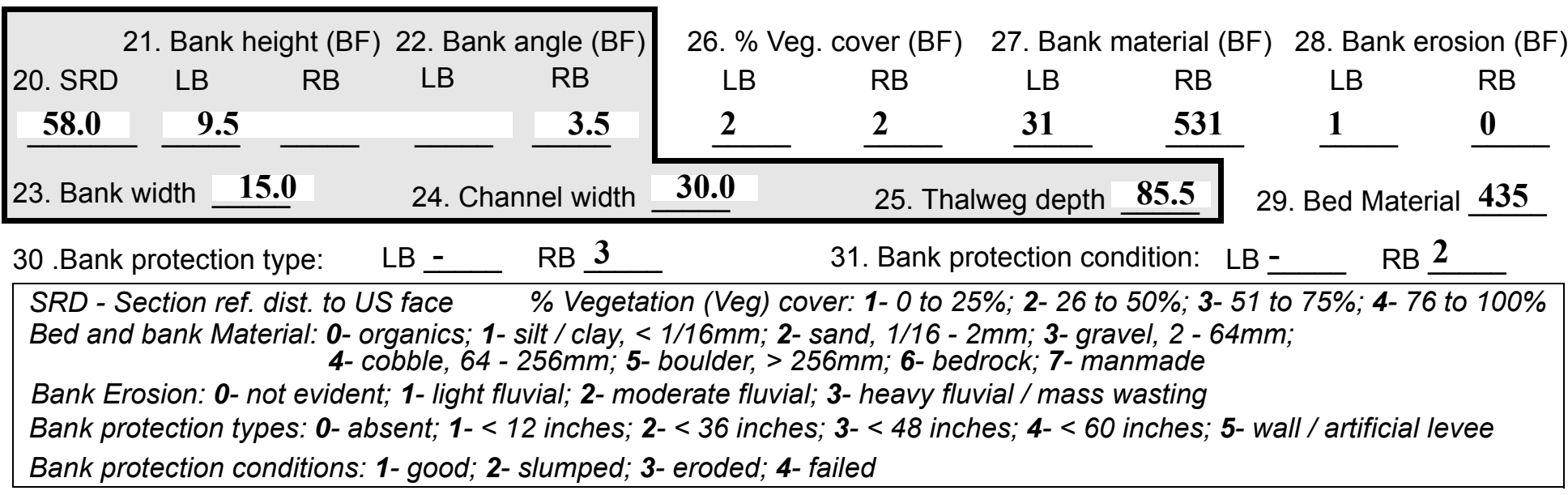

32. Comments (bank material variation, minor inflows, protection extent, etc.):

27. The left bank consists of gravels and silt. The right bank is composed of boulders, gravel and silt.

29. The bed material is cobble, gravel and boulder.

30. The right bank protection extends $192 \mathrm{ft}$. US of the bridge. 
33.Point/Side bar present? $\mathbf{N}(Y$ or $N$. if $N$ type ctrl-n pb)34. Mid-bar distance: -

35. Mid-bar width: -

36. Point bar extent: feet (US, UB) to feet (US, UB, DS) positioned $\%$ LB to $\% \mathrm{RB}$

37. Material:

38. Point or side bar comments (Circle Point or Side; Note additional bars, material variation, status, etc.):

NO POINT BARS

39. Is a cut-bank present? $\mathbf{Y}$ (Y or if $N$ type ctrl-n cb)

40. Where? $\underline{\mathbf{L B}}$ (LB or $R B)$

41. Mid-bank distance: $\mathbf{2 5 0}$

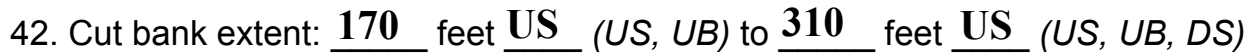

43. Bank damage: 1

(1- eroded and/or creep; 2- slip failure; 3- block failure)

44. Cut bank comments (eg. additional cut banks, protection condition, etc.):

The cut bank begins at about $310 \mathrm{ft}$. US to the bend in the channel $170 \mathrm{ft}$. US of the bridge.

\section{Is channel scour present? $\mathbf{Y}$ ( $Y$ or if $N$ type ctrl-n cs)}

46. Mid-scour distance: 93

47. Scour dimensions: Length $\mathbf{1 2 5}$

Width 10

Depth : $\underline{3.5}$

Position $\mathbf{7 5} \%$ LB to 100 \%RB

48. Scour comments (eg. additional scour areas, local scouring process, etc.):

Average thalweg depth is $1.5 \mathrm{ft}$. US and DS. Scour runs along the right bank from $65 \mathrm{ft}$. US to $190 \mathrm{ft}$. US.

49. Are there major confluences? $\mathbf{N}$

51. Confluence 1: Distance Confluence 2: Distance -

52. Enters on -

Enters on -

54. Confluence comments (eg. confluence name):

NO MAJOR CONFLUENCES
50. How many? -

53. Type(1-perennial; 2- ephemeral)

Type (1-perennial; 2-ephemeral)

\section{Under Bridge Channel Assessment}

55. Channel restraint (BF)? LB 2

56. Height (BF)
LB RB
44.0
58. Bank width (BF) -
(1- natural bank; 2- abutment; 3- artificial levee)

Bed and bank Material: 0- organics; 1- silt / clay, < 1/16mm; 2- sand, 1/16 - 2mm; 3- gravel, 2 - 64mm; 4- cobble, 64 - 256mm; 5- boulder, > 256mm; 6- bedrock; 7- manmade

Bank Erosion: 0- not evident; 1- light fluvial; 2- moderate fluvial; 3- heavy fluvial / mass wasting

64. Comments (bank material variation, minor inflows, protection extent, etc.):

345

63. The bed material is gravel, cobble and boulder.

The stream flow is along the right abutment. 
65. Debris and Ice Is there debris accumulation?

(Yor $N)$ 66. Where? $\underline{Y}$

(1- Upstream; 2- At bridge; 3- Both)

67. Debris Potential 1 (1-Low; 2-Moderate; 3- High)

68. Capture Efficiency 2

(1-Low; 2- Moderate; 3- High)

69. Is there evidence of ice build-up? 1 (Y or N)

Ice Blockage Potential $\mathbf{N}$

(1-Low; 2- Moderate; 3- High)

70. Debris and Ice Comments:

1

There is a low flood plain along the US right bank from $200 \mathrm{ft}$. US to $500 \mathrm{ft}$. US with dead trees. There are exposed roots along the upstream left cut bank.

\begin{tabular}{|l|c|c|c|c|c|c|c|c|}
\hline Abutments & $\begin{array}{c}\text { 71. Attack } \\
\angle \text { (BF) }\end{array}$ & $\begin{array}{c}72 \text {. Slope } \angle \\
\text { (Qmax) }\end{array}$ & $\begin{array}{c}\text { 73. Toe } \\
\text { loc. (BF) }\end{array}$ & $\begin{array}{c}\text { 74. Scour } \\
\text { Condition }\end{array}$ & $\begin{array}{c}75 . \text { Scour } \\
\text { depth }\end{array}$ & $\begin{array}{c}\text { 76. Exposure } \\
\text { depth }\end{array}$ & 77. Material & 78. Length \\
\hline LABUT & & $\mathbf{0}$ & $\mathbf{9 0}$ & $\mathbf{2}$ & $\mathbf{0}$ & $\mathbf{0}$ & $\mathbf{0}$ & $\mathbf{9 0 . 0}$ \\
\hline RABUT & $\mathbf{1}$ & $\mathbf{3 0}$ & $\mathbf{9 0}$ & & & $\mathbf{2}$ & $\mathbf{1}$ & $\mathbf{7 1 . 5}$ \\
\hline
\end{tabular}

Pushed: $L B$ or RB

Toe Location (Loc.): 0- even, 1- set back, 2- protrudes

Scour cond.: 0- not evident; 1- evident (comment); 2- footing exposed; 3-undermined footing; 4- piling exposed; 5- settled; 6- failed

Materials: 1- Concrete; 2- Stone masonry or drywall; 3- steel or metal; 4- wood

79. Abutment comments (eg. undermined penetration, unusual scour processes, debris, etc.):

0.5

0

1

The flow is along the right abutment as it is at the outside bank of a meander.

75. The right abutment scour is just beyond the slumped and eroded stone fill.

80. Wingwalls:

Exist? Material? Scour Scour Exposure $\begin{aligned} & 81 . \\ & \text { Angle? Length? }\end{aligned}$ Condition? depth? depth?

USLWW:

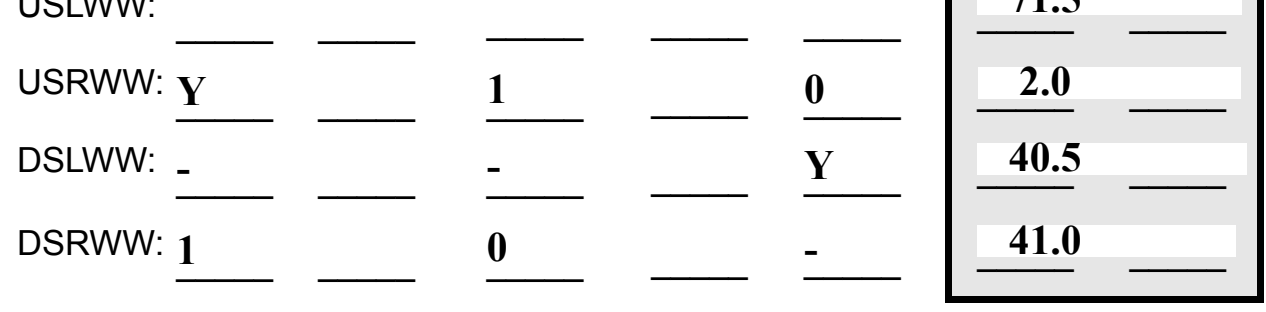

Wingwall materials: 1- Concrete; 2- Stone masonry or drywall; 3- steel or metal; 4- wood

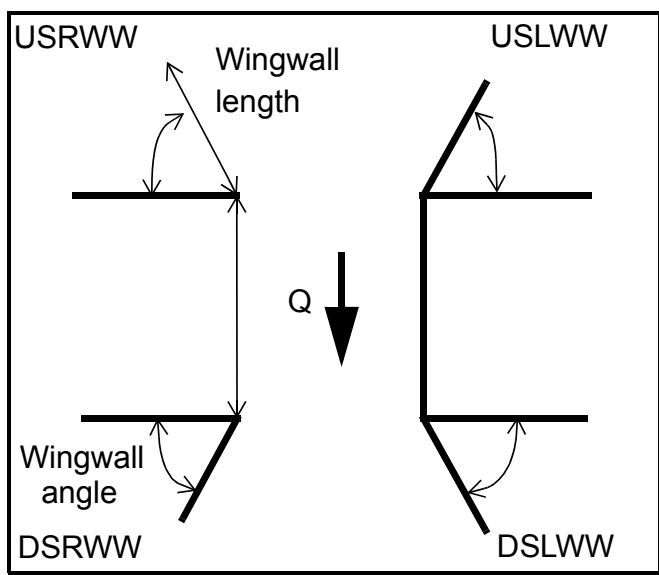

82. Bank / Bridge Protection:

\begin{tabular}{|l|l|l|l|l|l|l|l|c|}
\hline Location & USLWW & USRWW & LABUT & RABUT & LB & RB & DSLWW & DSRWW \\
\hline Type & - & $\mathbf{0}$ & $\mathbf{Y}$ & - & - & $\mathbf{2}$ & - & $\mathbf{3}$ \\
\hline Condition & $\mathbf{Y}$ & - & $\mathbf{1}$ & - & - & $\mathbf{1}$ & - & $\mathbf{1}$ \\
\hline Extent & $\mathbf{1}$ & - & $\mathbf{0}$ & $\mathbf{0}$ & $\mathbf{3}$ & $\mathbf{0}$ & $\mathbf{2}$ & - \\
\hline
\end{tabular}

Bank / Bridge protection types: 0- absent; 1- < 12 inches; 2- < 36 inches; 3- < 48 inches; 4- < 60 inches; 
83. Wingwall and protection comments (eg. undermined penetration, unusual scour processes, etc.):

-
-
-
-
-
0
-
-
3
2
1

\section{Piers:}

84. Are there piers? Th (Y or if $N$ type ctrl-n pr)

\begin{tabular}{|l|l|l|l|l|l|l|l|}
\hline \multirow{2}{*}{$\begin{array}{l}85 . \\
\text { Pier no. }\end{array}$} & \multicolumn{3}{|c|}{ width (w) feet } & \multicolumn{5}{c|}{ elevation (e) feet } \\
\cline { 2 - 8 } & w1 & w2 & w3 & e@w1 & e@w2 & e@w3 \\
\hline Pier 1 & & & & $\mathbf{4 5 . 0}$ & $\mathbf{1 7 . 0}$ & $\mathbf{4 5 . 0}$ \\
\hline Pier 2 & & & & $\mathbf{1 0 . 0}$ & $\mathbf{4 5 . 0}$ & $\mathbf{1 3 . 5}$ \\
\hline Pier 3 & & & - & $\mathbf{4 5 . 0}$ & $\mathbf{1 0 . 0}$ & - \\
\hline Pier 4 & - & - & - & - & - & - \\
\hline
\end{tabular}

\begin{tabular}{|l|l|l|l|l|}
\hline Level 1 Pier Descr. & \multicolumn{1}{|c|}{1} & 2 & 3 & \multicolumn{1}{|c|}{} \\
\hline 86. Location (BF) & e & & - & - \\
\hline 87. Type & right & & - & - \\
\hline 88. Material & abut & & - & - \\
\hline 89. Shape & ment & & - & - \\
\hline 90. Inclined? & pro- & & - & - \\
\hline 91. Attack $\angle$ (BF) & tec- & & - & - \\
\hline 92. Pushed & tion & & - & - \\
\hline 93. Length (feet) & - & - & - & - \\
\hline 94. \# of piles & is & & - & - \\
\hline 95. Cross-members & sub- & & - & - \\
\hline 96. Scour Condition & merg & N & - & - \\
\hline 97. Scour depth & ed. & - & - & - \\
\hline 98. Exposure depth & & - & - & - \\
\hline
\end{tabular}

LFP, LTB, LB, MCL, MCM, MCR, RB, RTB, RFP

1- Solid pier, 2- column, 3- bent

1-Wood; 2- concrete; 3- metal; 4- stone

1- Round; 2- Square; 3- Pointed

Y-yes; $N-$ no

$L B$ or $R B$

0- none; 1- laterals; 2- diagonals; 3- both

0- not evident; 1- evident (comment);

2- footing exposed; 3- piling exposed;

4- undermined footing; 5- settled; 6-failed 
99. Pier comments (eg. undermined penetration, protection and protection extent, unusual scour processes, etc.):

-
-
-
-
-
-
-
-
-

100.

\section{E. Downstream Channel Assessment}

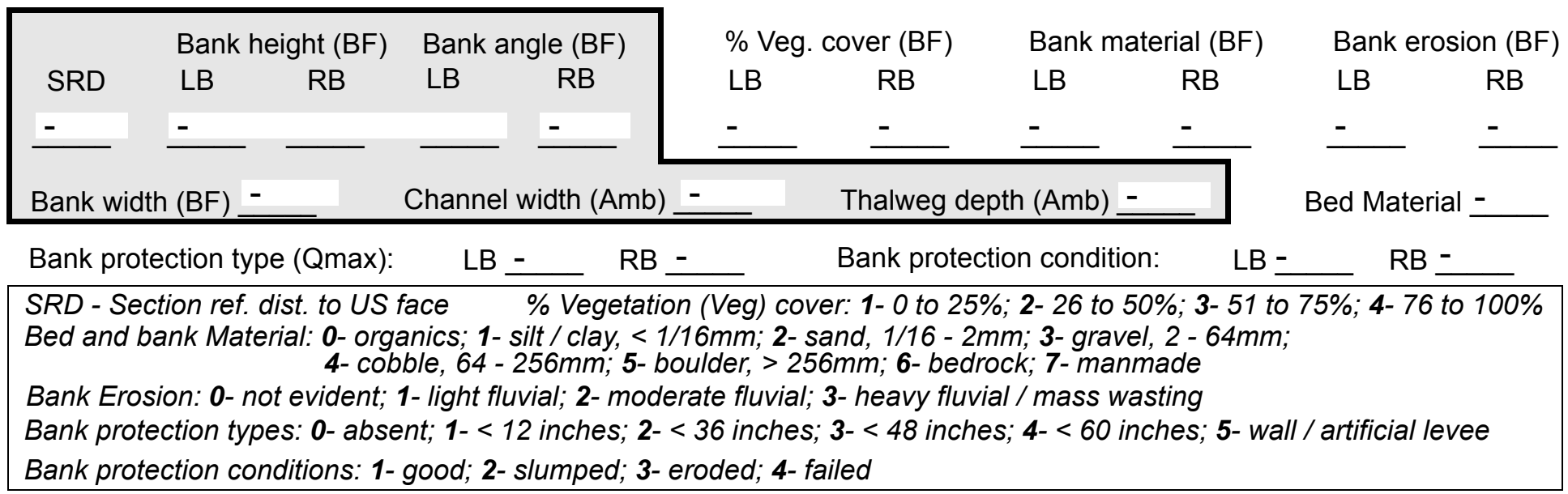

Comments (eg. bank material variation, minor inflows, protection extent, etc.): $-$

NO PIERS

2

1

45

45

101. Is a drop structure present? $\mathbf{2}$ (Y or $N$, if $N$ type ctrl-n ds) 102. Distance: __ feet 103. Drop: -_ feet 104. Structure material: 1 (1- steel sheet pile; 2- wood pile; 3- concrete; 4- other) 105. Drop structure comments (eg. downstream scour depth):

345

0

2

-

2

The bank material consists of cobbles and boulders in silt material. The bed consists of gravel, cobbles, and 


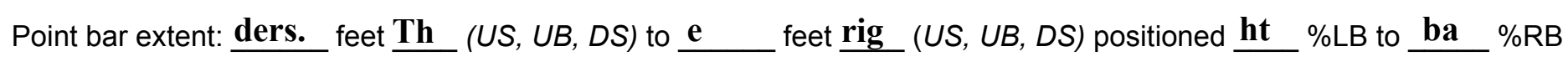
Material: $\mathbf{n k}$

Point or side bar comments (Circle Point or Side; note additional bars, material variation, status, etc.):

protection extends $205 \mathrm{ft}$. DS.

At $190 \mathrm{ft}$. DS the channel anabranches and then merges back at $275 \mathrm{ft}$.

At $320 \mathrm{ft}$. DS on the left bank there is mass wasting of the bank with some downed live trees.

Is a cut-bank present? (Y or if $N$ type ctrl-n cb) Where? (LB or $R B)$

Mid-bank distance:

Cut bank extent: feet (US, UB, DS) to feet (US, UB, DS)

Bank damage: (1- eroded and/or creep; 2- slip failure; 3- block failure)

Cut bank comments (eg. additional cut banks, protection condition, etc.):

$\mathbf{N}$

$-$

NO DROP STRUCTURE

Is channel scour present? (Y or if $N$ type ctrl-n cs)

Mid-scour distance:

Scour dimensions: Length Width Depth:

Positioned $\underline{\mathbf{Y}} \%$ LB to $\underline{\mathbf{0}}$ \%RB

Scour comments (eg. additional scour areas, local scouring process, etc.):

50

12

US

109

Are there major confluences? DS ( $Y$ or if $N$ type ctrl-n $m c$ )

How many? 0

Confluence 1: Distance 65

Enters on $\underline{32}$ ( $L B$ or $R B$ )

Type This (1-perennial; 2- ephemeral)

Confluence 2: Distance is a

Enters on grav ( $L B$ or $R B$ )

Type el (1- perennial; 2- ephemeral)

Confluence comments (eg. confluence name):

and sand point bar with vegetation at mid-bar and DS of the bridge with some flow through the middle of the bar.

\section{F. Geomorphic Channel Assessment}

107. Stage of reach evolution

1- Constructed

2- Stable

3- Aggraded

4- Degraded

5- Laterally unstable

6- Vertically and laterally unstable 
108. Evolution comments (Channel evolution not considering bridge effects; See HEC-20, Figure 1 for geomorphic descriptors):

Y

RB

180

150

DS

220

DS

1

There is slight erosion of the fines from the bank and slumping protection. There is mass wasting/block failure at $320 \mathrm{ft}$. DS on the left bank. 


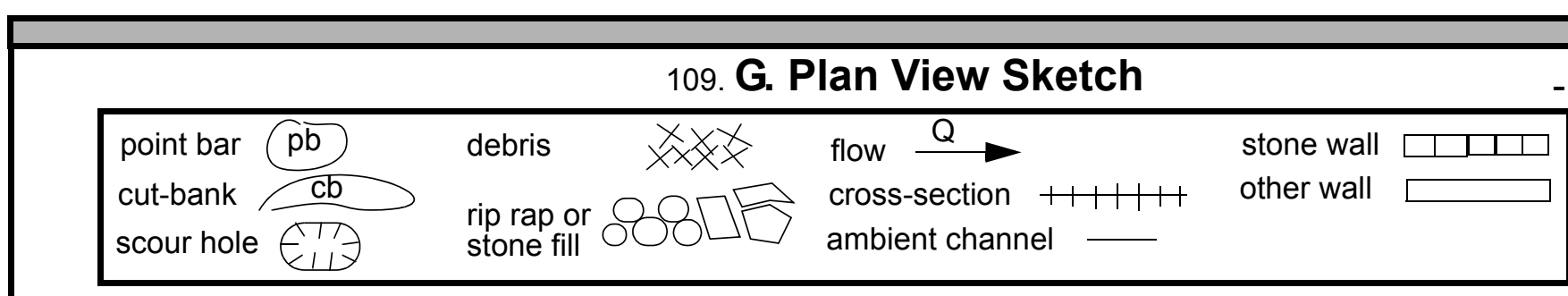


APPENDIX F:

SCOUR COMPUTATIONS 


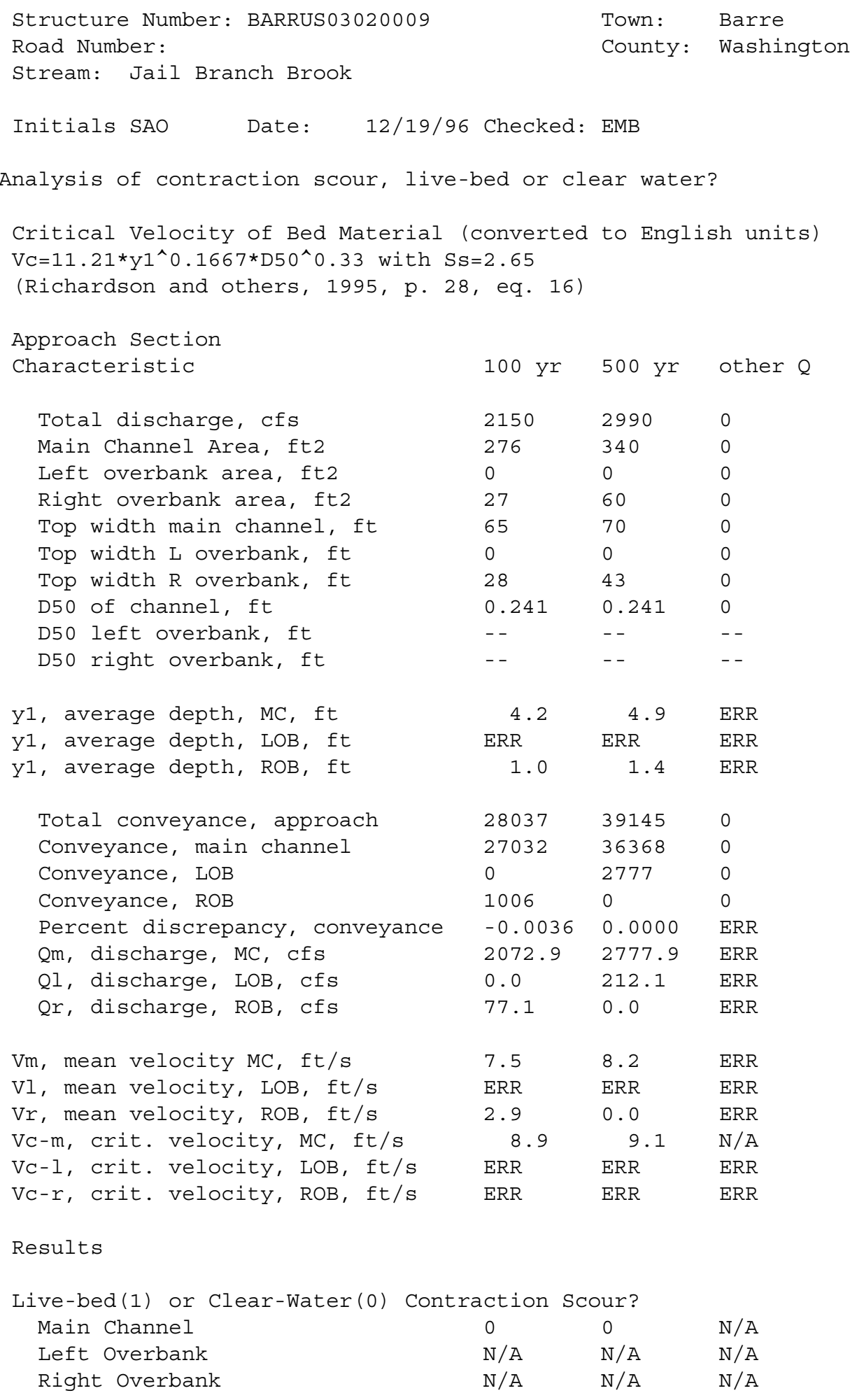




\begin{tabular}{|c|c|c|c|}
\hline \multicolumn{3}{|l|}{$\begin{array}{l}\mathrm{y} 2=\left(\mathrm{Q} 2^{\wedge} 2 /\left(131 * \mathrm{Dm}^{\wedge}(2 / 3) * \mathrm{~W} 2^{\wedge} 2\right)\right)^{\wedge}(3 / 7) \\
\mathrm{ys}=\mathrm{y} 2-\mathrm{y} \text { bridge }\end{array}$} & \multirow[t]{2}{*}{ English Units } \\
\hline (Richardson and others, 1995, p. & , eq. 20 & $20 a)$ & \\
\hline Approach Section & Q100 & Q500 & Qother \\
\hline Main channel Area, ft2 & 276 & 340 & 0 \\
\hline Main channel width, ft & 65 & 70 & 0 \\
\hline y1, main channel depth, ft & 4.25 & 4.86 & ERR \\
\hline \multicolumn{4}{|l|}{ Bridge section } \\
\hline (Q) total discharge, cfs & 2150 & 2990 & 0 \\
\hline (Q) discharge thru bridge, cfs & 2150 & 2990 & 0 \\
\hline Main channel conveyance & 18090 & 25380 & 0 \\
\hline Total conveyance & 18090 & 25380 & 0 \\
\hline Q2, bridge MC discharge, cfs & 2150 & 2990 & ERR \\
\hline Main channel area, ft2 & 218 & 271 & 0 \\
\hline Main channel width (skewed), ft & 72.1 & 72.1 & 0.0 \\
\hline Cum. width of piers in MC, ft & 0.0 & 0.0 & 0.0 \\
\hline w, adjusted width, ft & 72.1 & 72.1 & 0 \\
\hline y_bridge (avg. depth at br.), ft & 3.02 & 3.76 & ERR \\
\hline Dm, median $(1.25 * \mathrm{D} 50)$, ft & 0.30125 & 0.30125 & 0 \\
\hline $\mathrm{y}^{2}$, depth in contraction, ft & 3.20 & 4.25 & ERR \\
\hline ys, scour depth (y2-ybridge), ft & 0.18 & 0.49 & $\mathrm{~N} / \mathrm{A}$ \\
\hline \multicolumn{4}{|l|}{ ARMORING } \\
\hline D90 & 0.423 & 0.423 & 0 \\
\hline D95 & 0.500 & 0.500 & 0 \\
\hline Critical grain size,Dc, ft & 0.4911 & 0.5590 & ERR \\
\hline Decimal-percent coarser than DC & 0.0551 & 0.0164 & 0 \\
\hline Depth to armoring, ft & 25.27 & $\mathrm{~N} / \mathrm{A}$ & ERR \\
\hline
\end{tabular}




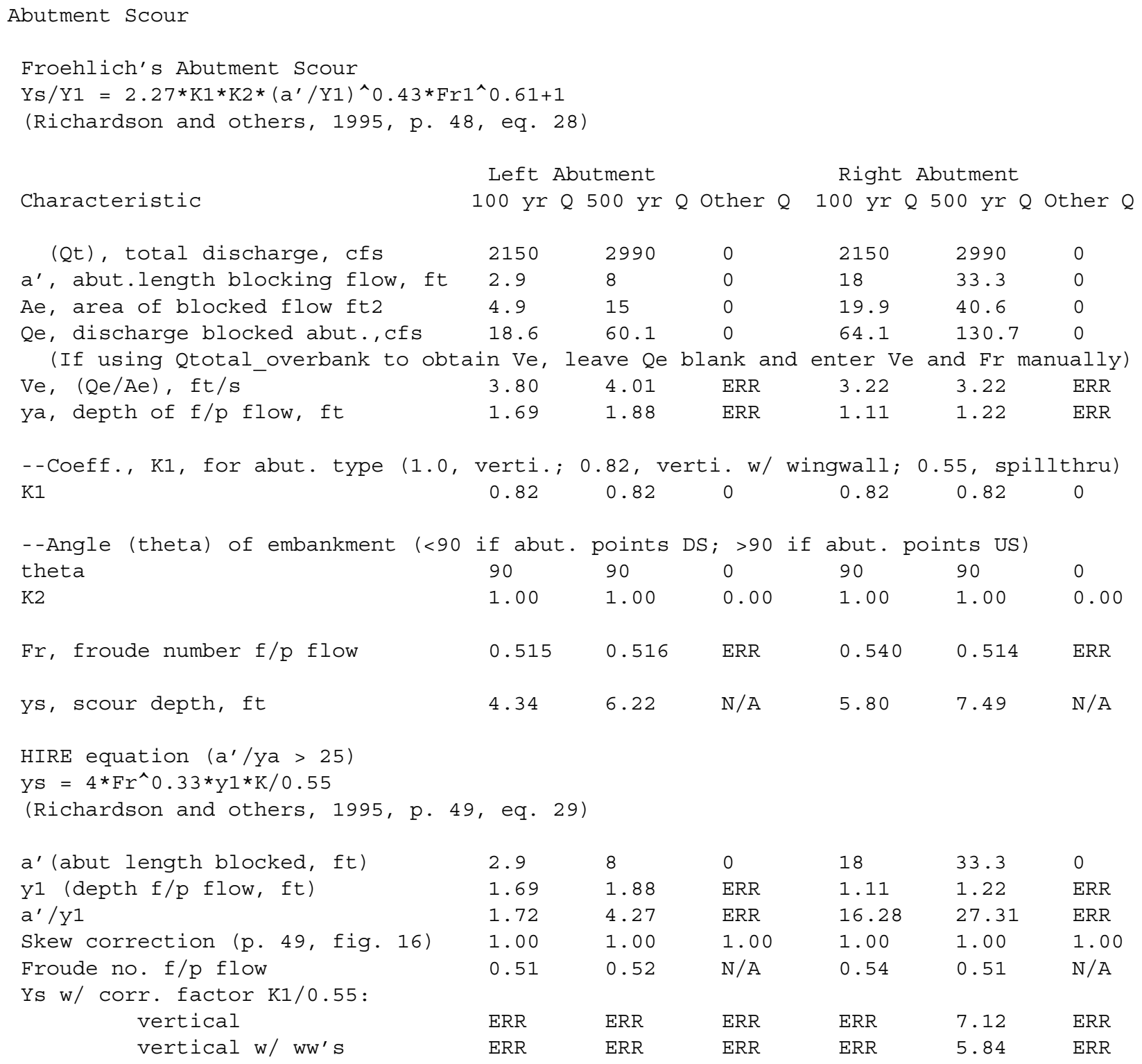




\begin{tabular}{|c|c|c|c|c|c|c|}
\hline spill-through & ERR & ERR & ERR & ERR & 3.91 & ERR \\
\hline \multicolumn{7}{|l|}{ Abutment riprap Sizing } \\
\hline \multicolumn{7}{|c|}{$\begin{array}{l}\text { Isbash Relationship } \\
\mathrm{D} 50=\mathrm{Y}^{\star} \mathrm{K} * \mathrm{Fr} r^{\wedge} 2 /(\mathrm{Ss}-1) \text { and } \mathrm{D} 50=\mathrm{Y} * \mathrm{~K} *\left(\mathrm{Fr} r^{\wedge} 2\right)^{\wedge} 0.14 /(\mathrm{Ss}-1) \\
\text { (Richardson and others, 1995, p112, eq. 81,82) }\end{array}$} \\
\hline Characteristic & Q100 & Q500 & Qother & & & \\
\hline $\begin{array}{l}\text { Fr, Froude Number } \\
\quad \text { (Fr from the characteristic } V \text { and }\end{array}$ & $\begin{array}{l}1 \\
y\end{array}$ & $\begin{aligned} & 1 \\
\text { eract } & \text { ract }\end{aligned}$ & $\begin{array}{l}0 \\
\text { ection }\end{array}$ & i br & $\begin{array}{l}1 \\
\text { sect }\end{array}$ & 0 \\
\hline$y$, depth of flow in bridge, ft & 3.02 & 3.76 & 0.00 & 3.02 & 3.76 & 0.00 \\
\hline \multicolumn{4}{|c|}{ Median stone Diameter for riprap at: left abutment } & righ & atmen & \\
\hline Fr<=0.8 (vertical abut.) & ERR & ERR & 0.00 & ERR & ERR & 0.00 \\
\hline Fr>0.8 (vertical abut.) & 1.26 & 1.57 & $\mathrm{ERR}$ & 1.26 & 1.57 & ERR \\
\hline Fr<=0.8 (spillthrough abut.) & ERR & ERR & 0.00 & ERR & ERR & 0.00 \\
\hline Fr>0.8 (spillthrough abut.) & 1.12 & 1.39 & ERR & 1.12 & 1.39 & ERR \\
\hline
\end{tabular}

